\title{
Forest response to increased disturbance in the central Amazon and comparison to western Amazonian forests
}

\author{
J. A. Holm ${ }^{1}$, J. Q. Chambers ${ }^{1,2}$, W. D. Collins ${ }^{1,3}$, and N. Higuchi ${ }^{4}$ \\ ${ }^{1}$ Lawrence Berkeley National Laboratory, Berkeley, California 94720, USA \\ ${ }^{2}$ Department of Geography, University of California, Berkeley, California 94720, USA \\ ${ }^{3}$ Department of Earth and Planetary Science, University of California, Berkeley, California 94720, USA \\ ${ }^{4}$ Departamento de Silvicultura Tropical, Manejo Florestal, Instituto Nacional de Pesquisas da Amazônia, \\ Av. André Araújo, 2936 Petrópolis, Manaus AM, Brasil \\ Correspondence to: J. A. Holm (jaholm@lbl.gov)
}

Received: 10 April 2014 - Published in Biogeosciences Discuss.: 28 May 2014

Revised: 25 August 2014 - Accepted: 15 September 2014 - Published: 20 October 2014

\begin{abstract}
Uncertainties surrounding vegetation response to increased disturbance rates associated with climate change remains a major global change issue for Amazonian forests. Additionally, turnover rates computed as the average of mortality and recruitment rates in the western Amazon basin are doubled when compared to the central Amazon, and notable gradients currently exist in specific wood density and aboveground biomass (AGB) between these two regions. This study investigates the extent to which the variation in disturbance regimes contributes to these regional gradients. To address this issue, we evaluated disturbance-recovery processes in a central Amazonian forest under two scenarios of increased disturbance rates using first ZELIG-TROP, a dynamic vegetation gap model which we calibrated using longterm inventory data, and second using the Community Land Model (CLM), a global land surface model that is part of the Community Earth System Model (CESM). Upon doubling the mortality rate in the central Amazon to mirror the natural disturbance regime in the western Amazon of $\sim 2 \%$ mortality, the two regions continued to differ in multiple forest processes. With the inclusion of elevated natural disturbances, at steady state, AGB significantly decreased by $41.9 \%$ with no significant difference between modeled AGB and empirical AGB from the western Amazon data sets (104 vs. $107 \mathrm{MgC} \mathrm{ha}^{-1}$, respectively). However, different processes were responsible for the reductions in AGB between the models and empirical data set. The empirical data set suggests that a decrease in wood density is a driver leading to the reduction in AGB. While decreased stand basal area was
\end{abstract}

the driver of AGB loss in ZELIG-TROP, a forest attribute that does not significantly vary across the Amazon Basin. Further comparisons found that stem density, specific wood density, and basal area growth rates differed between the two Amazonian regions. Last, to help quantify the impacts of increased disturbances on the climate and earth system, we evaluated the fidelity of tree mortality and disturbance in CLM. Similar to ZELIG-TROP, CLM predicted a net carbon loss of $49.9 \%$, with an insignificant effect on aboveground net primary productivity (ANPP). Decreased leaf area index (LAI) was the driver of AGB loss in CLM, another forest attribute that does not significantly vary across the Amazon Basin, and the temporal variability in carbon stock and fluxes was not replicated in CLM. Our results suggest that (1) the variability between regions cannot be entirely explained by the variability in disturbance regime, but rather potentially sensitive to intrinsic environmental factors; or (2) the models are not accurately simulating all tropical forest characteristics in response to increased disturbances.

\section{Introduction}

One of the largest uncertainties in future terrestrial sources of atmospheric carbon dioxide results from changes to forest disturbance and tree mortality rates, specifically in tropical forests (Cox et al., 2000, 2004; DeFries et al., 2002; Clark, 2007; Pan et al., 2011). There has been evidence that climate change and forest disturbance are linked such that a changing 
climate can influence the timing, duration, and intensity of disturbance regimes (Overpeck et al., 1990; Dale et al., 2001; Anderegg et al., 2013). In the tropics, climate change related impacts such as water and heat stress, and increased vulnerability to fires could lead to increased forest dieback (i.e., tree mortality notably higher than usual mortality) and increased disturbance rates (Cox et al., 2004; Malhi et al., 2008, 2009; US DOE, 2012). Increased forest dieback in tropical locations could then produce large economic costs, ecological impacts, and lead to climate related positive feedback cycles (Canham and Marks, 1985; Dale et al., 2001; Laurance and Williamson, 2001; Bonan, 2008).

The effects of large-scale removal of tropical forest, leading to changes in global climate, have been studied within global general circulation models (GCMs) (Shukla et al., 1990; Henderson-Sellers et al., 1993; Hahmann and Dickinson, 1997; Gedney and Valdes, 2000; Avissar and Werth, 2005). For example, a rapid and complete deforestation of the diverse Amazon Basin was predicted to be irreversible (Shukla et al., 1990), losing $\sim 180 \mathrm{Gt}$ carbon. These past studies have simulated extreme deforestation, or complete removal of the tropical forest biome, with the goal of evaluating climate impacts (i.e., albedo, evaporation, precipitation, surface boundary conditions). However, instead of sudden and complete removal, gradual increases and spatially heterogeneous patterns of tropical tree mortality due to multiple causes are more likely to occur than complete loss (Fearnside 2005; Morton et al., 2006). In addition, the effectiveness of climate mitigation strategies will be affected by future changes in natural disturbances regimes (IPCC, 2014; Le Page et al., 2013), due to the effect of disturbances on the terrestrial carbon balance. By using an economic/energy integrated assessment model, it was found that when natural disturbance rates are doubled and in order to reach a stringent mitigation target, $\left(3.7 \mathrm{~W} \mathrm{~m}^{-2}\right.$ level) the societal, technological, and economic strategies will be up to 2.5 times more costly (Le Page et al., 2013). Due to the strong feedbacks from terrestrial processes, there is a need to utilize an integrated Earth System Model approach (i.e., iESM; Jones et al., 2013), where an integrated assessment model is coupled with a biogeochemical and biophysical climate model such as CLM and CESM. It is necessary to improve earth system models in order to simulate dynamic disturbance rates and gradual forest biomass loss in response to increasing mortality rates.

Turnover rates currently vary for different regions of Amazonia (Baker et al., 2004a, b; Lewis et al., 2004; Phillips et al., 2004; Chao et al., 2009), with central Amazonian forests having "slower" turnover rates, and the western and southern Amazonian forests (which we call "west and south") exhibiting "faster" turnover rates. This regional variation in turnover rates is connected with differences in carbon stocks, growth rates, specific wood density, and biodiversity. Baker et al. (2004a) investigated regional-scale AGB estimates, concluding that differences in species composition and re- lated specific wood density determined the regional patterns in AGB. There is a strong west-east gradient in that "west and south" Amazonian forests were found to have significantly lower AGB than their eastern counterparts; also confirmed by additional studies (Malhi et al., 2006; Baraloto et al., 2011).

It is unclear if these regional variations in forest processes and carbon stocks are driven by external disturbance (e.g., increased drought, windstorm, forest fragmentation) or internal influences (e.g., soil quality, phosphorus limitation, species composition, wood density) (Phillips et al., 2004; Chao et al., 2009; Quesada et al., 2010; Yang et al., 2013). Investigating the causes that drive variation in tree dynamics in the Amazon, in order to understand consequences for future carbon stocks for each region should still be explored. For example, are the differences in forest structure and function between the two regions a result of the disturbance regime? If the central Amazonian forests were subject to a higher disturbance regime and turnover rates similar to that of the "west and south", would the two regions match in terms of forest dynamics, carbon stocks and fluxes? A goal of this paper is to use modeling tools to explore the influence of disturbance regimes on net carbon stocks and fluxes in the central Amazon, and then compare to observational data from the "west and south" regions of the Amazon.

We are using an individual-based, demographic, gap model (Botkin et al., 1972; Shugart, 2002) as a "benchmark" model to (1) evaluate the influence of disturbance on net carbon loss and variations in forest dynamics between two regions (central vs. "west and south"), (2) evaluate disturbance and mortality in CLM-CN 4.5 (called CLM for remainder of paper), and (3) improve upon representing terrestrial feedbacks more accurately in earth system modeling. We used the dynamic vegetation gap model ZELIG (Cumming and Burton 1993; Urban et al., 1993). ZELIG has been updated and modified to simulate a tropical forest in Puerto Rico with a new versatile disturbance routine (ZELIG-TROP; Holm et al., 2012), making this vegetation dynamic model a good choice for this study.

Vegetation and carbon response to increased disturbance rates resulting from human induced climate change must be examined in more detail. To test how a widely used global land surface model, CLM, forecasts changes in forest carbon sinks and sources, we addressed differences in AGB, ANPP, growth rates, and coarse litter production rates as a result of disturbances. The main research questions of the study are (1) what are the long-term consequences of continual elevated disturbance rates and periodic, large-scale disturbances in the central Amazon? (2) Can the variability in forest dynamics, carbon stocks, and fluxes between the western and southern Amazon and the central Amazonian forests be explained by the variability in the natural disturbance regime (i.e., higher mortality rates)? Finally, (3) what are the differences after increasing disturbance rates in ZELIGTROP vs. CLM for the central Amazon? We are assuming an 
independent driver of mortality; therefore, we are not assigning mortality to any particular cause. The final research question will evaluate the accuracy of CLM to predict changes to carbon fluxes due to increased disturbance, a process that is likely to increase with human induced climate change.

\section{Methods}

\subsection{Study area and forest inventory plots}

The empirical data used for this study were from two permanent transects inventoried from 1996 to 2006, located in reserves of the National Institute for Amazon Research (Instituto Nacional de Pequisas da Amazonia, INPA) in the central Amazon in Brazil. The forest inventory transects are approximately $60 \mathrm{~km}$ north of Manaus, Brazil, in the central Amazon where vegetation is old-growth closed-canopy tropical evergreen forest. The mean annual precipitation at Manaus was $2110 \mathrm{~mm} \mathrm{yr}^{-1}$ with a dry season from July to September, and mean annual temperature was $26.7^{\circ} \mathrm{C}$ (Chambers et al., 2004; National Oceanic and Atmospheric Administration, National Climatic Data Center, Asheville, N.C., USA). However, during 2003-2004, mean annual precipitation in the study area reached $2739 \mathrm{~mm} \mathrm{yr}^{-1}$.

We quantified demographic data such as stem density, diameter at breast height $(\mathrm{DBH}, \mathrm{cm})$, and change in diameter for trees $>10 \mathrm{~cm}$ DBH from census data from the two transects. This data was used to calculate aboveground biomass (ABG) estimates $\left(\mathrm{Mg} \mathrm{Cha}^{-1}\right)$ and were determined using region-specific allometric equations after harvesting 315 trees in the central Amazon (Chambers et al., 2001; see Eq. 1 below). This data was also used to estimate observed values for aboveground net primary productivity (ANPP, $\mathrm{MgC} \mathrm{ha}^{-1} \mathrm{yr}^{-1}$ ) after taking into account loss of tree mass due to tree damage (Chambers et al., 2001). Observed mortality rates ( $\%$ stems $\mathrm{yr}^{-1}$ ) were based on census intervals ranging from 1 to $5 \mathrm{yr}$ on 211 ha undisturbed plots located in the Biomass and Nutrient Experiment (BIONTE), and the Biological Dynamics and Forest Fragments Project (BDFFP), also located in INPA (Chambers et al., 2004). We compared model predictions from ZELIG-TROP to observed field data.

In order to test whether the variability in forest dynamics and carbon stocks between the "west and south" and the central Amazonian forests can be explained by the variability in the natural disturbance regime, we used forest inventory data collected and reported in Baker et al. (2004a) and Phillips et al. (2004). We used inventory data collected from 59 plots as reported in Baker et al. (2004a, b), and from 97 plots as reported in Phillips et al. (2004) with these plots constituting a large part of the RAINFOR Amazonian forest inventory network (Malhi et al., 2002). Sites occur across a large range of environmental gradients, such as varying soil types and level of seasonal flooding; however, all sites are considered to be mature tropical forests. We then compared the central
Amazonian forests (both simulated and observed data) to the observed "west and south" data sets.

\subsection{Description of ZELIG-TROP}

ZELIG-TROP is an individual-based gap model developed to simulate tropical forests (Holm et al., 2012). It is derived from the gap model ZELIG (Urban, 1990, 2000; Urban et al., 1991, 1993), which is based on the original principles of the JABOWA (Botkin et al., 1972) and FORET forest gap models (Shugart and West, 1977). ZELIG-TROP follows the regeneration, growth, development, and death of each individual tree within dynamic environmental conditions across many plots $\left(400 \mathrm{~m}^{2}\right.$ plots, replicated uniquely 100 times). Maximum potential tree behaviors (e.g., optimal tree establishment, diameter growth, and survival rates) are reduced as a function of light conditions, soil moisture, level of soil fertility resources, and temperature. Specific details on the ZELIG model modifications to create ZELIG-TROP can be found in Holm et al. (2012). Gap models have been used extensively to forecast forest change from varying types and levels of disturbances, such as windstorms and hurricanes (O’Brien et al., 1992; Mailly et al., 2000); simulate vegetation dynamics in response to global change (Solomon, 1986; Smith and Urban, 1988; Smith and Tirpak, 1989; Overpeck et al., 1990; Shugart et al., 1992); and explore feedbacks between climate change and vegetation cover (Shuman et al., 2011; Lutz et al., 2013). ZELIG has been used to simulate forest succession dynamics in many forest types across the globe (O'Brien et al., 1992; Seagle and Liang, 2001; Busing and Solomon, 2004; Larocque et al., 2006; Nakayama, 2008). (Descriptions of the plant mortality algorithm as well as definitions of terms and parameters used in ZELIG-TROP are provided in the Supplement.)

\subsubsection{Model parameterization for the central Amazon}

The silvicultural and biological parameters for each of the 90 tropical tree species required for ZELIG-TROP are found in Table 1. The 90 tree species consist of 25 different families, 54 canopy species, 18 emergent species, 12 sub-canopy species, and 6 pioneer species (Table 1). While these tree species do not represent all existing species found in the central Amazonian forest, they represent a diverse array of family types, canopy growth forms, and demographic traits such as growth rates, stress tolerances, and recruitment variations that will produce a robust and reliable result. The majority of the data used to parameterize ZELIG-TROP for the Amazon was derived from a long-term (14-18 yr) demographic study to estimate tree longevity (Laurance et al., 2004) located in central Amazon. Data was collected on 3159 individual trees from 24 permanent, 1 ha plots which span across an area of $1000 \mathrm{~km}^{2}$ (Laurance et al., 2004). Wood density data for the 90 species used in this study were gathered from published 
Table 1. Species-specific allometric and ecological parameters for the 90 tree species used in ZELIG-TROP, representing species found in central Amazonian (Laurance et al., 2004). All species were assigned a probability factor of stress mortality of 0.369, probability factor of natural mortality of 2.813, zone of seed influence of 200, relative seedling establishment rate (RSER) of 0.9 , a crown shape value of 4.0, tolerance to drought a ranking of 3 , tolerance to low soil nutrients a ranking of 2 , minimum growing degree day of 5000 , and a maximum growing degree day of 12229.50 .

\begin{tabular}{|c|c|c|c|c|c|c|c|c|c|c|}
\hline Species & Growth form & Age max & DBH max & HT max & $G$ & $\mathrm{~L}$ & $\mathrm{D}$ & $\mathrm{N}$ & Stock & Wood density \\
\hline Anacardium spruceanum & Canopy & 175 & 69.1 & 3620.4 & 75.2 & 2 & 3 & 2 & 0.8 & 0.46 \\
\hline Aniba canelilla & Canopy & 226 & 37.8 & 2032.8 & 38.7 & 2 & 3 & 2 & 0.5 & 0.94 \\
\hline Aspidosperma marcgravianum & Emergent & 544 & 90.0 & 4680.4 & 30.8 & 4 & 3 & 2 & 0.5 & 0.72 \\
\hline Aspidosperma oblongum & Emergent & 331 & 80.0 & 4173.2 & 59.5 & 4 & 3 & 2 & 0.5 & 0.87 \\
\hline Astronium le-cointei & Canopy & 335 & 50.0 & 2651.6 & 34.7 & 2 & 3 & 2 & 0.5 & 0.77 \\
\hline Bocageopsis multiflora & Canopy & 152 & 33.1 & 1794.5 & 51.3 & 2 & 3 & 2 & 0.5 & 0.65 \\
\hline Brosimum acutifolium & Canopy & 264 & 58.3 & 3072.6 & 36.2 & 2 & 3 & 2 & 0.5 & 0.62 \\
\hline Brosimum guianense & Canopy & 477 & 60.0 & 3158.8 & 22.3 & 2 & 3 & 2 & 0.5 & 0.89 \\
\hline Brosimum parinarioides & Canopy & 483 & 60.0 & 3158.8 & 24.9 & 2 & 3 & 2 & 0.5 & 0.62 \\
\hline Brosimum rubescens & Canopy & 450 & 60.0 & 3158.8 & 27.1 & 2 & 3 & 2 & 0.5 & 0.84 \\
\hline Cariniana micrantha & Emergent & 223 & 80.0 & 4173.2 & 76.5 & 4 & 3 & 2 & 0.5 & 0.60 \\
\hline Caryocar glabrum & Canopy & 527 & 110.0 & 5694.8 & 32.1 & 2 & 3 & 2 & 0.5 & 0.71 \\
\hline Casearia arborea & Canopy & 91 & 20.1 & 1135.1 & 39.1 & 2 & 3 & 2 & 0.8 & 0.57 \\
\hline Casearia sylvestris & Canopy & 201 & 25.5 & 1409.0 & 23.7 & 2 & 3 & 2 & 0.5 & 0.71 \\
\hline Clarisia racemosa & Canopy & 323 & 80.0 & 4173.2 & 44.7 & 2 & 3 & 2 & 0.5 & 0.57 \\
\hline Cordia sagotli & Subcanopy & 260 & 26.3 & 1449.6 & 14.6 & 1 & 3 & 2 & 0.8 & 0.43 \\
\hline Corythophora rimosa & Canopy & 235 & 50.0 & 2651.6 & 48.1 & 2 & 3 & 2 & 0.5 & 0.81 \\
\hline Couepia longipendula & Canopy & 260 & 46.6 & 2479.2 & 37.7 & 2 & 3 & 2 & 0.5 & 0.94 \\
\hline Couma macrocarpa & Canopy & 233 & 51.8 & 2742.9 & 56.8 & 2 & 3 & 2 & 0.8 & 0.50 \\
\hline Couratari stellata & Emergent & 592 & 53.5 & 2829.1 & 13.4 & 4 & 3 & 2 & 0.5 & 0.63 \\
\hline Dipteryx odorata & Emergent & 323 & 78.4 & 4092.1 & 47.7 & 4 & 3 & 2 & 0.5 & 0.92 \\
\hline Drypetes variabilis & Subcanopy & 252 & 30.0 & 1637.2 & 23.7 & 1 & 3 & 2 & 0.5 & 0.73 \\
\hline Duckeodendron cestroides & Emergent & 818 & 140.0 & 7216.4 & 18.8 & 4 & 3 & 2 & 0.5 & 0.63 \\
\hline Ecclinusa guianensis & Canopy & 448 & 69.7 & 3650.8 & 28.5 & 2 & 3 & 2 & 0.5 & 0.63 \\
\hline Endopleura uchi & Canopy & 223 & 57.6 & 3037.1 & 52.5 & 2 & 3 & 2 & 0.5 & 0.79 \\
\hline Eriotheca globosa & Canopy & 135 & 20.1 & 1135.1 & 28.3 & 2 & 3 & 2 & 0.8 & 0.41 \\
\hline Eschweilera amazoniciformis & Emergent & 369 & 56.1 & 2961.0 & 30.5 & 4 & 3 & 2 & 0.5 & 0.82 \\
\hline Eschweilera coriacea & Canopy & 767 & 110.0 & 5694.8 & 25.7 & 2 & 3 & 2 & 0.5 & 0.84 \\
\hline Fusaea longifolia & Subcanopy & 413 & 26.5 & 1459.7 & 11.5 & 1 & 3 & 2 & 0.5 & 0.74 \\
\hline Glycydendron amazonicum & Canopy & 386 & 44.0 & 2347.3 & 23.8 & 2 & 3 & 2 & 0.5 & 0.67 \\
\hline Goupia glabra & Emergent & 398 & 100.0 & 5187.6 & 44.7 & 4 & 3 & 2 & 0.5 & 0.72 \\
\hline Guatteria olivacea & Canopy & 54 & 30.0 & 1637.2 & 126.4 & 2 & 3 & 2 & 0.8 & 0.47 \\
\hline Gustavia elliptica & Subcanopy & 301 & 24.7 & 1368.4 & 16.8 & 1 & 3 & 2 & 0.5 & 0.67 \\
\hline Helicostylis tomentosa & Canopy & 311 & 44.7 & 2382.8 & 24.0 & 2 & 3 & 2 & 0.5 & 0.63 \\
\hline Hevea guianensis & Canopy & 288 & 45.7 & 2433.5 & 29.3 & 2 & 3 & 2 & 0.5 & 0.55 \\
\hline Inga capitata & Pioneer & 162 & 26.4 & 1454.6 & 27.6 & 3 & 3 & 2 & 0.7 & 0.60 \\
\hline Inga paraensis & Pioneer & 78 & 40.0 & 2144.4 & 95.2 & 3 & 3 & 2 & 0.7 & 0.82 \\
\hline Inga splendens & Pioneer & 52 & 38.2 & 2053.1 & 157.6 & 3 & 3 & 2 & 0.7 & 0.58 \\
\hline Iryanthera juruensis & Subcanopy & 569 & 26.9 & 1480.0 & 8.8 & 1 & 3 & 2 & 0.5 & 0.66 \\
\hline Iryanthera laevis & Subcanopy & 331 & 27.2 & 1495.2 & 15.4 & 1 & 3 & 2 & 0.5 & 0.63 \\
\hline Jacaranda copaia & Pioneer & 225 & 30.0 & 1637.2 & 21.0 & 3 & 3 & 2 & 0.8 & 0.35 \\
\hline Lecythis barnebyi & Subcanopy & 336 & 28.7 & 1571.3 & 19.9 & 1 & 3 & 2 & 0.5 & 0.82 \\
\hline Lecythis poiteaui & Canopy & 747 & 34.4 & 1860.4 & 7.7 & 2 & 3 & 2 & 0.5 & 0.80 \\
\hline Lecythis zabucajo & Emergent & 628 & 130.0 & 6709.2 & 27.0 & 4 & 3 & 2 & 0.5 & 0.86 \\
\hline
\end{tabular}


Table 1. Continued.

\begin{tabular}{|c|c|c|c|c|c|c|c|c|c|c|}
\hline Species & Growth form & Age max & DBH max & HT max & $G$ & $\mathrm{~L}$ & $\mathrm{D}$ & $\mathrm{N}$ & Stock & Wood density \\
\hline Licania apetala & Canopy & 199 & 38.4 & 2063.3 & 37.8 & 2 & 3 & 2 & 0.5 & 0.76 \\
\hline Licania oblongifolia & Canopy & 196 & 54.2 & 2864.6 & 65.7 & 2 & 3 & 2 & 0.5 & 0.88 \\
\hline Licania octandra & Subcanopy & 339 & 35.0 & 1890.8 & 21.7 & 1 & 3 & 2 & 0.5 & 0.81 \\
\hline Licania cannella & Canopy & 359 & 56.5 & 2981.3 & 29.0 & 2 & 3 & 2 & 0.5 & 0.79 \\
\hline Macrolobium angustifolium & Canopy & 335 & 40.0 & 2144.4 & 27.7 & 2 & 3 & 2 & 0.5 & 0.68 \\
\hline Manilkara bidentata & Emergent & 773 & 90.0 & 4680.4 & 20.6 & 4 & 3 & 2 & 0.5 & 0.87 \\
\hline Manilkara huberi & Emergent & 349 & 100.0 & 5187.6 & 55.9 & 4 & 3 & 2 & 0.5 & 0.93 \\
\hline Maquira sclerophylla & Emergent & 420 & 60.0 & 3158.8 & 24.0 & 4 & 3 & 2 & 0.5 & 0.53 \\
\hline Mezilaurus itauba & Canopy & 684 & 44.0 & 2347.3 & 12.9 & 2 & 3 & 2 & 0.5 & 0.74 \\
\hline Micropholis guyanensis & Canopy & 248 & 55.5 & 2930.6 & 45.9 & 2 & 3 & 2 & 0.5 & 0.66 \\
\hline Micropholis venulosa & Canopy & 491 & 60.0 & 3158.8 & 22.9 & 2 & 3 & 2 & 0.5 & 0.67 \\
\hline Minquartia guianensis & Emergent & 490 & 70.0 & 3666.0 & 30.4 & 4 & 3 & 2 & 0.5 & 0.77 \\
\hline Myrciaria floribunda & Subcanopy & 490 & 29.1 & 1591.6 & 11.7 & 1 & 3 & 2 & 0.5 & 0.77 \\
\hline Onychopetalum amazonicum & Canopy & 195 & 29.9 & 1632.1 & 33.0 & 2 & 3 & 2 & 0.5 & 0.61 \\
\hline Parkia multijuga & Emergent & 206 & 119.0 & 6151.3 & 101.7 & 4 & 3 & 2 & 0.8 & 0.39 \\
\hline Peltogyne paniculata & Canopy & 251 & 40.0 & 2144.4 & 28.0 & 2 & 3 & 2 & 0.5 & 0.80 \\
\hline Pourouma bicolor & Pioneer & 48 & 29.8 & 1627.1 & 124.6 & 3 & 3 & 2 & 0.8 & 0.38 \\
\hline Pourouma guianensis & Pioneer & 58 & 31.3 & 1703.2 & 112.8 & 3 & 3 & 2 & 0.8 & 0.38 \\
\hline Pouteria ambelaniifolia & Canopy & 296 & 38.0 & 2043.0 & 21.0 & 2 & 3 & 2 & 0.5 & 0.70 \\
\hline Pouteria anomala & Emergent & 452 & 70.0 & 3666.0 & 31.6 & 4 & 3 & 2 & 0.5 & 0.78 \\
\hline Pouteria caimito & Canopy & 240 & 43.2 & 2306.7 & 36.4 & 2 & 3 & 2 & 0.5 & 0.82 \\
\hline Pouteria eugeniifolia & Canopy & 329 & 44.1 & 2352.4 & 25.8 & 2 & 3 & 2 & 0.5 & 1.10 \\
\hline Pouteria guianensis & Canopy & 720 & 80.0 & 4173.2 & 17.5 & 2 & 3 & 2 & 0.5 & 0.94 \\
\hline Pouteria macrophylla & Canopy & 387 & 29.6 & 1616.9 & 13.2 & 2 & 3 & 2 & 0.5 & 0.86 \\
\hline Pouteria manaosensis & Canopy & 981 & 50.0 & 2651.6 & 8.4 & 2 & 3 & 2 & 0.5 & 0.64 \\
\hline Pouteria multiflora & Canopy & 547 & 35.5 & 1916.2 & 9.5 & 2 & 3 & 2 & 0.5 & 0.75 \\
\hline Pouteria oppositifolia & Canopy & 277 & 35.8 & 1931.4 & 21.7 & 2 & 3 & 2 & 0.5 & 0.65 \\
\hline Pouteria venosa & Canopy & 702 & 45.8 & 2438.6 & 10.0 & 2 & 3 & 2 & 0.5 & 0.92 \\
\hline Protium altsonii & Emergent & 238 & 70.0 & 3666.0 & 56.4 & 4 & 3 & 2 & 0.5 & 0.68 \\
\hline Protium decandrum & Canopy & 158 & 32.8 & 1779.2 & 40.3 & 2 & 3 & 2 & 0.5 & 0.52 \\
\hline Protium heptaphyllum & Canopy & 96 & 26.2 & 1444.5 & 60.0 & 2 & 3 & 2 & 0.8 & 0.62 \\
\hline Protium tenuifolium & Canopy & 170 & 38.2 & 2053.1 & 49.1 & 2 & 3 & 2 & 0.5 & 0.57 \\
\hline Qualea paraensis & Emergent & 379 & 70.0 & 3666.0 & 31.9 & 4 & 3 & 2 & 0.5 & 0.67 \\
\hline Scleronema micranthum & Emergent & 353 & 90.0 & 4680.4 & 50.3 & 4 & 3 & 2 & 0.5 & 0.60 \\
\hline Sloanea guianensis & Subcanopy & 179 & 28.5 & 1561.1 & 26.8 & 1 & 3 & 2 & 0.5 & 0.82 \\
\hline Swartzia corrugata & Subcanopy & 407 & 21.1 & 1185.8 & 7.7 & 1 & 3 & 2 & 0.5 & 1.06 \\
\hline Swartzia recurva & Canopy & 177 & 38.4 & 2063.3 & 45.5 & 2 & 3 & 2 & 0.5 & 0.97 \\
\hline Swartzia ulei & Canopy & 293 & 50.0 & 2651.6 & 39.1 & 2 & 3 & 2 & 0.5 & 1.00 \\
\hline Tachigali paniculata & Canopy & 91 & 27.7 & 1520.6 & 60.1 & 2 & 3 & 2 & 0.8 & 0.56 \\
\hline Tapirira guianensis & Canopy & 54 & 41.6 & 2225.6 & 188.0 & 2 & 3 & 2 & 0.8 & 0.45 \\
\hline Tetragastris panamensis & Canopy & 320 & 38.4 & 2063.3 & 25.1 & 2 & 3 & 2 & 0.5 & 0.72 \\
\hline Vantanea parviflora & Canopy & 205 & 69.6 & 3645.7 & 65.1 & 2 & 3 & 2 & 0.5 & 0.84 \\
\hline Virola calophylla & Subcanopy & 293 & 30.8 & 1677.8 & 18.6 & 3 & 2 & 2 & 0.8 & 0.51 \\
\hline Virola multinervia & Canopy & 373 & 32.0 & 1738.7 & 14.0 & 2 & 3 & 2 & 0.8 & 0.45 \\
\hline Virola sebifera & Canopy & 161 & 30.2 & 1647.4 & 44.4 & 2 & 3 & 2 & 0.8 & 0.46 \\
\hline Vochysia obidensis & Canopy & 92 & 47.4 & 2519.7 & 109.1 & 2 & 3 & 2 & 0.8 & 0.50 \\
\hline
\end{tabular}

Key: AGEMAX, maximum age for the species (yr); DBH max, maximum diameter at breast height (cm); HT max, maximum height (cm); $G$, growth-rate scaling coefficient (unitless); light (L): light/shade tolerance class (ranking 1-5); stock, regeneration stocking (\%), wood density $\left(\mathrm{g} \mathrm{cm}^{-3}\right)$; (full parameter explanation found in original ZELIG paper: Urban, 1990). 
Table 2. Environmental parameters used in ZELIG-TROP for the central Amazon basin. Values reported in a range were monthly low and high averages.

\begin{tabular}{lcccccc}
\hline $\begin{array}{l}\text { Lat./long./ } \\
\text { alt. }(\mathrm{m})\end{array}$ & $\begin{array}{l}\text { Plot } \\
\text { area } \\
\left(\mathrm{m}^{2}\right)\end{array}$ & $\begin{array}{c}\text { Mean monthly } \\
\text { temperature } \\
\left({ }^{\circ} \mathrm{C}\right)\end{array}$ & $\begin{array}{c}\text { Mean monthly } \\
\text { precipitation } \\
(\mathrm{cm})\end{array}$ & $\begin{array}{c}\text { Soil field } \\
\text { capacity } \\
(\mathrm{cm})\end{array}$ & $\begin{array}{c}\text { Soil } \\
\text { wilting } \\
\text { point }(\mathrm{cm}))^{\mathrm{a}}\end{array}$ & $\begin{array}{c}\text { Relative direct } \\
\text { and diffuse solar } \\
\text { radiation }(\%)\end{array}$ \\
\hline $\begin{array}{l}-2.3 /-60.0 / \\
100.0\end{array}$ & 400.0 & $25.18-27.47$ & $8.01-45.16$ & 52.0 & 32.9 & $0.6 / 0.4$ \\
\hline
\end{tabular}

${ }^{\mathrm{a}}$ Laurance et al. (1999).

sources with sites across South America (Fearnside, 1997; Chave et al., 2006).

We used results found by Laurance et al. (2004) to determine several parameters; specifically the maximum age of the species (AGEMAX), the maximum diameter at breast height $\left(\mathrm{DBH}_{\max }, \mathrm{cm}\right)$, and the growth-rate scaling coefficient $(G)$ for ZELIG-TROP. AGEMAX was found by taking the mean of three longevity estimates. $\mathrm{DBH}_{\max }$ were scaled to match a more accurate representation of maximum DBH in the simulated field sites (Chambers et al., 2004). We used the canopy classification as described by Laurance et al. (2004) to infer species-specific rankings for tolerance and intolerance to shading. Average monthly precipitation $(\mathrm{cm})$ and temperature $\left({ }^{\circ} \mathrm{C}\right)$ required for the environmental parameters in ZELIG-TROP (Table 2) were based on field data collected from 2002 to 2004 in the study site (Tribuzy, 2005). Soil field capacity $(\mathrm{cm})$ and soil wilting point $(\mathrm{cm})$ were determined from soil measurements in nearby central Amazon study sites (Laurance et al., 1999).

In order to more accurately simulate the central Amazonian forest, a few modifications were made to the original ZELIG-TROP model (Holm et al., 2012). First, the allometric equation used to estimate aboveground biomass $\left(\mathrm{MgC} \mathrm{ha}^{-1}\right)$ was updated to include an equation specific for the Brazilian rain forest in the central Amazon (Chambers et al., 2001; Eq. 1).

$\ln (\operatorname{mass})=\alpha+\beta_{1} \ln (\mathrm{DBH})+\beta_{2}[\ln (\mathrm{DBH})]^{2}+\beta_{3}[\ln (\mathrm{DBH})]^{3}$,

where aboveground biomass (mass) is in $\mathrm{kg}, \alpha$ is $-0.370, \beta_{1}$ is $0.333, \beta_{2}$ is 0.933 , and $\beta_{3}$ is $-0.122\left(r_{\text {adj }}^{2}=0.973\right)$ based upon data collected from 315 harvested trees. Specific wood density is not taken into account in this model.

In model development of the original ZELIG-TROP (modified for a subtropical dry forest), death caused by natural mortality (age-related) was killing tropical trees prematurely. This was also seen in initial model testing for the wet tropical forest. In contrast to tropical dry forests, individuals in tropical wet forests have a longer life potential and a higher likelihood of reaching their potential size. For example, the central Amazon is able to support trees $>1000 \mathrm{yr}$ old (Chambers et al., 1998, 2001; Laurance et al., 2004), where a dry forest may only be able to support trees to a maximum of $400 \mathrm{yr}$. To adjust for this variation, the natural survivorship rate was increased from 1.5 to $6 \%$ of trees surviving to their maximum age (Table 1). This was a conservative value, with one study estimating about $15 \%$ of species in central Amazon attaining their maximum ages (Laurance et al., 2004). Lastly, we also modified ZELIG-TROP's mean available light growing factor algorithm, which in part was used to accurately calculate tree height and crown interaction effects, as developed in ZELIG-CFS (Larocque et al., 2011). To best portray tree growth and crown development typical of an individual within a tropical canopy, we used an earlier algorithm version developed for ZELIG-CFS. This algorithm was the ratio of available growing light factor (ALGF) to a doubled crown width for each individual, thereby adjusting the ALGF relative to horizontal space occupied by the crown and improving the predictive capacities of ZELIG-TROP for the Amazon. This modification thus affected the light extinction on tree growth, allowed more available light from the top to the bottom of the individual-tree crown, and in turn better predicted observed data of basal area growth and abundance of stems per plot.

\subsubsection{Verification methods}

ZELIG-TROP simulations for the central Amazonian forest were run for $500 \mathrm{yr}$ and replicated on 100 independent plots, each the size of $400 \mathrm{~m}^{2}$. All simulations began from bare ground, and results from ZELIG-TROP were averaged over the final $100 \mathrm{yr}$ of simulation. This was the period when forest dynamics (e.g., stem density, AGB, ANPP) were seen to reach a stable state and represent a mature forest stand. The model was verified by comparing the following five simulated forest attributes (average $\pm \mathrm{SD}$ ) to observed field data from the two inventory transects: (1) total basal area $\left(\mathrm{m}^{2} \mathrm{ha}^{-1}\right)$, (2) total AGB $\left(\mathrm{Mg} \mathrm{Cha}^{-1}\right)$, (3) total stem density $\left(\mathrm{ha}^{-1}\right)$, (4) leaf area index, and (5) ANPP $\left(\mathrm{Mg} \mathrm{Cha}^{-1} \mathrm{yr}^{-1}\right)$. To test model validity for the central Amazonian forest, we report percent difference between the observed and simulated results (Table 3).

\subsection{Disturbance treatments}

To better understand the long-term consequences of high disturbance in a central Amazon rain forest, we crafted a simulation that doubled annual background tree mortality in both 
Table 3. Averages (and standard deviations) of five forest attributes for the observed values recorded from sites near Manaus, Brazil, averaged over $5 \mathrm{ha}$, and the modeled ZELIG-TROP results. ZELIG-TROP results are averaged for the final $100 \mathrm{yr}$, after an initial spin up of $400 \mathrm{yr}$. The remaining values correspond to the percent differences between the observed and simulated values, and the minimum and maximum range of a ZELIG-TROP simulation.

\begin{tabular}{|c|c|c|c|c|c|}
\hline & $\begin{array}{c}\text { Avg. basal } \\
\text { Area }\left(\mathrm{m}^{2} \mathrm{ha}^{-1}\right)\end{array}$ & $\begin{array}{l}\text { Avg. biomass } \\
\left(\mathrm{MgCha}^{-1}\right)\end{array}$ & $\begin{array}{c}\text { Avg. stem } \\
\text { Density }\left(\mathrm{ha}^{-1}\right)\end{array}$ & $\begin{array}{c}\text { Avg. LAI } \\
\left(\mathrm{MgCha}^{-1} \mathrm{yr}^{-1}\right)\end{array}$ & Avg. ANPP \\
\hline Empirical data & $30.06(6.61)$ & $169.84(27.60)$ & $656(22)$ & $5.7(0.50)$ & 6.5 \\
\hline ZELIG-TROP & $32.96(1.22)$ & $178.38(10.53)$ & $574(70)$ & $5.8(0.24)$ & $5.4(0.22)$ \\
\hline Percent diff. (\%) & 9.66 & 5.03 & -12.49 & 1.75 & -17.08 \\
\hline ZELIG-TROP min./max. & $31.14 / 35.97$ & $167.97 / 189.26$ & $472 / 688$ & $5.26 / 6.48$ & $5.08 / 5.92$ \\
\hline
\end{tabular}

ZELIG-TROP and CLM assuming an independent mechanism as the driver of mortality. A description of the Community Land Model (CLM) can be found in the supplementary materials. Predicting the impacts of increased mortality is critical since other recent studies have found that tree mortality in the central Amazon has been undersampled in plotbased approaches, and after analyzing a larger range of gap sizes (including larger gaps), $\sim 9.1$ to $16.9 \%$ of tree mortality was missing (Chambers et al., 2013). The majority of gaps created in Amazonian rain forests are from windthrow of canopy trees with a large percentage of gaps having relatively small areas of $<200 \mathrm{~m}^{2}$ (Uhl, 1982; Denslow, 1987; Stanford, 1990). However, some windthrow events will create large gaps that then initiate secondary succession processes (Brokaw, 1985, Chambers et al., 2013). Since there can be multiple spatial scales and drivers of tree mortality, we are simulating mortality as a stochastic, independent event within ZELIG-TROP, using the new versatile disturbance routine implemented in Holm et al. (2012). Most mortality events in the central Amazon occur on individual trees (Chambers et al., 2004, 2013). Therefore, this phenomenon was replicated in the model. Specifically, any one tree $>10 \mathrm{~cm}$ DBH was randomly selected to die and be removed from the forest canopy on an annual basis at the gap scale, in addition to the existing selection of trees removed by natural senescence. This "high-disturbance" treatment for the central Amazonian forests is representative of the current turnover rates in "west and south" (Phillips et al., 2004), thus creating an opportunity to test whether the variability in forest dynamics and carbon stocks between the "west and south" and the central Amazonian forests can be explained by the variability in the natural disturbance regime. Variables compared between the two regions included AGB, wood density (Baker et al., 2004a), recruitment rates, and stem density (Phillips et al., 2004), and stand-level BA growth rates (Lewis et al., 2004).

A second treatment has been applied in order to improve understanding of periodic large-scale disturbance and recovery events. This treatment consisted of removing $20 \%$ of stems $>10 \mathrm{~cm} \mathrm{DBH}$ every $50 \mathrm{yr}$ (i.e., periodic treatment). It has recently been noted that patch-scale $\left(400 \mathrm{~m}^{2}\right)$ succession-inducing disturbances exhibit a return frequency of about $50 \mathrm{yr}$ within the central Amazon region (Chambers et al., 2013). Therefore we have set our large-scale disturbance event to repeat four times over a 200 year period (every $50 \mathrm{yr}$ ) after the forest has reached a mature stable state. This treatment was also conducted in both ZELIG-TROP and CLM. An important metric in determining the forest carbon balance as a result of disturbance is the total change in stand biomass over time ( $\triangle \mathrm{AGB}, \mathrm{Mg} \mathrm{Cha}^{-1}$ ), defined as $\mathrm{AGB}_{t 2}-$ $\mathrm{AGB}_{t 1}$ over the simulation period.

\section{Results}

\subsection{Model verification results}

Results simulated by ZELIG-TROP for the mature central Amazon tropical forest (pre-disturbance treatment) were in close range (e.g., within $17 \%$ ) to empirical data (Table 3), making ZELIG-TROP successful at predicting stand dynamics of a complex tropical forest. Average basal area was $9.7 \%$ higher than the observed value ( 32.96 vs. $30.06 \mathrm{~m}^{2} \mathrm{ha}^{-1}$ ), average AGB was $5.0 \%$ higher (178.38 vs. $169.84 \mathrm{Mg} \mathrm{Cha}^{-1}$ ), and average leaf area index (LAI) was $1.8 \%$ higher $(5.8$ vs. 5.7). ZELIG-TROP predicted average stem density to be $12.5 \%$ lower ( 574 vs. 656 stems ha $^{-1}$ ), and ANPP was $17.1 \%$ lower than observed values reported by Chambers et al. (2001) (5.4 vs. $6.5 \mathrm{MgCha}^{-1} \mathrm{yr}^{-1}$ ). ZELIG-TROP was also successful at accurately predicting stem density and AGB by DBH $(\mathrm{cm})$ size class (Fig. 1a, c). The model over predicted the number of stems in the lowest size class $(10-20 \mathrm{~cm})$, by an additional 84 stems per hectare, and in the eighth size class $(80-90 \mathrm{~cm})$, but for the remaining size classes values were near to the observed data. Even with these slight over predictions in certain DBH size classes, the model predicted AGB to be within a reasonable range $\left(8.5 \mathrm{MgC} \mathrm{ha}^{-1}\right)$ of the observed values $\left(r^{2}=0.60\right)$.

ZELIG-TROP was also able to predict a realistic community composition (Fig. 2a). After initiating the model from bare ground, there was a sudden increase in basal area per species, followed by a typical jigsaw pattern of die-offs and growth increases, with the model reaching a steady state 

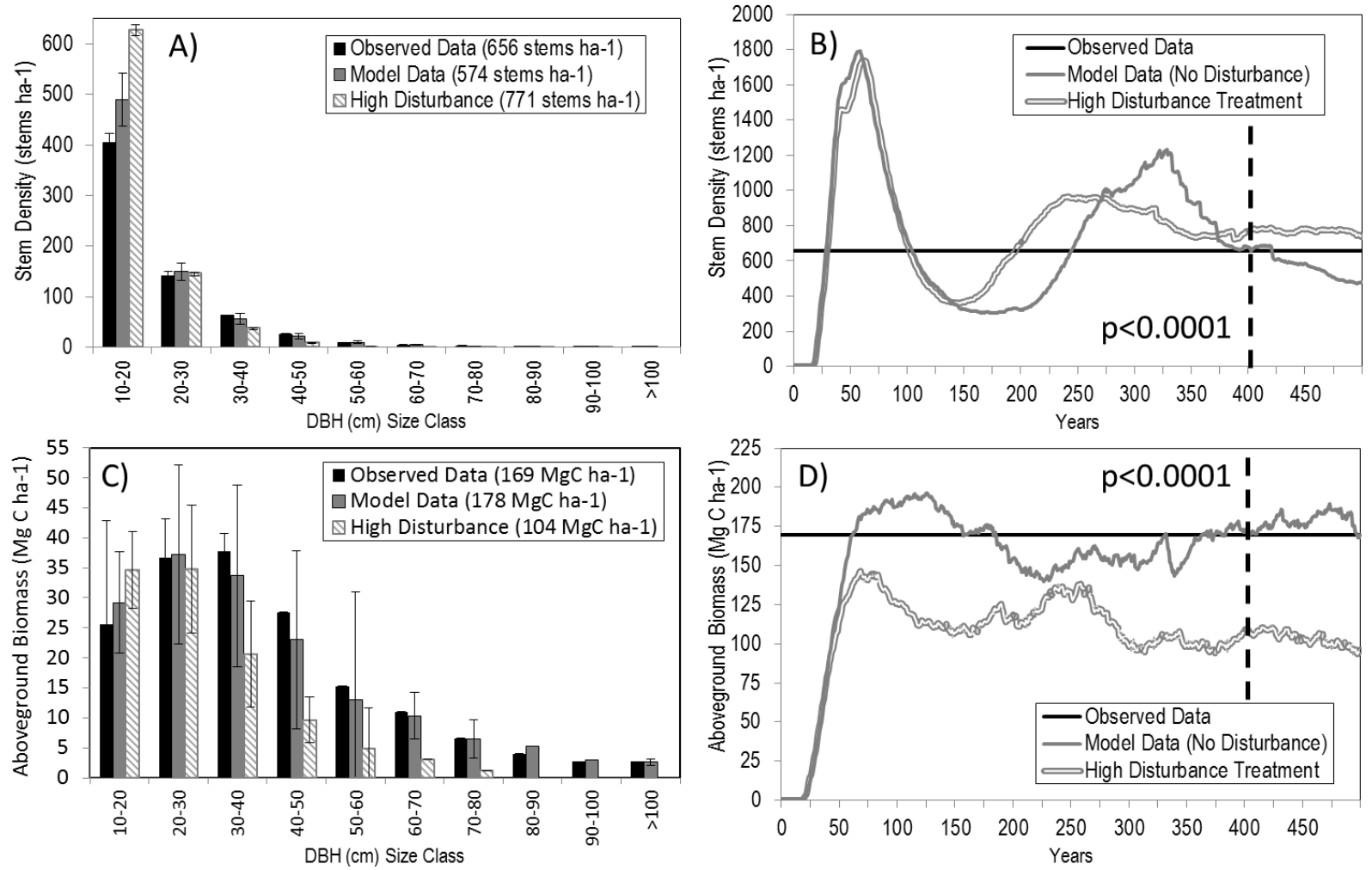

Figure 1. Comparison between observed field data from "transects" in central Amazon, ZELIG-TROP model data from no-disturbance scenario, and ZELIG-TROP model data from high-disturbance treatment. (a) Average stem density (stems ha ${ }^{-1}$ ) and SD by DBH (cm) size class, (b) stem density simulated over $500 \mathrm{yr}$, (c) average aboveground biomass $\left(\mathrm{Mg} \mathrm{ha}^{-1}\right)$ and SD by DBH (cm) size class, and (d) aboveground biomass simulated over $500 \mathrm{yr}$. Average results and $t$ test between two model results taken once the model reached a steady state, or the final $100 \mathrm{yr}$ of simulation.

during the last $100 \mathrm{yr}$. The dominant species in terms of basal area, Parkia multijuga, a large, fast-growing emergent species from the Leguminosae family accounted for $17 \%$ of the total basal area in the last $100 \mathrm{yr}$ of simulation. The next four dominant species were all canopy-level species. This was an accurate representation of the forest, as the canopy layer consists of many tree crowns, large trees, and usually a dense area of biodiversity (Wirth et al., 2001). For example, $63 \%$ of the 90 tree species simulated were categorized as a canopy growth form. However, there was also an even mixture of emergent, sub-canopy, and pioneer species as dominant and rare species, typical of a diverse central Amazonian forest. There was no one single species that dominated the canopy throughout the course of the simulation. Instead, we saw a diverse species representation (Fig. 2a). During the last $100 \mathrm{yr}$ of simulation, emergent species represented $29.6 \%$ of the total basal area, sub-canopy species represented $1.7 \%$, and pioneer species represented $5.5 \%$ of the total basal area.

Empirical mortality rates $\left(\% \mathrm{stems}^{-1}\right)$ from BDFFP and BIONTE data were lognormally distributed averaging $1.02 \pm 1.72 \%$ (Chambers et al., 2004). As estimated by ZELIG-TROP, the no-disturbance annual mortality rates were near to observed values $(1.27 \pm 0.21 \%)$ but had a smaller distribution around the mean (Fig. 3). As expected, annual mortality rate doubled $(2.66 \pm 0.26 \%)$ for the highdisturbance treatment.

\subsection{Central and western amazon disturbance comparisons}

\subsubsection{AGB, stem density, growth and recruitment rates}

Upon increasing the turnover rates of the central Amazonian forest to mirror the $\sim 2 \% \mathrm{yr}^{-1}$ mortality rates in the "west and south", the two Amazon regions continued to differ in forest structure and function. Stem density, specific wood density, basal area growth rates, and AGB from the treatment site did not match the trends observed in the "west and south" plot network. Using a Tukey's multiple comparison procedure following a one-way ANOVA, there was a significant difference in both wood density and basal area growth rates between the two regions in the empirical data set, but no significant difference in the model results (Fig. 4). Alternatively, when comparing stem density there was no significant difference between the two regions in the empirical data 
Table 4. Comparison of empirical data and stand model data from Chambers et al. (2004) unless otherwise noted, ZELIG-TROP pre- and post-disturbance treatments, and CLM pre- and post-disturbance treatments for the pool of carbon in live trees, and the annual flux of carbon from stem growth, coarse litter production rates from mortality, ANPP; and recruitment rate of stems, mean DBH, and average $\triangle \mathrm{AGB}$.

\begin{tabular}{|c|c|c|c|c|c|c|c|}
\hline $\begin{array}{l}\text { Positive } \\
=\operatorname{sink}\end{array}$ & $\begin{array}{c}\text { Live } \\
\text { trees } \\
\left(\mathrm{MgCha}^{-1}\right)\end{array}$ & $\begin{array}{c}\text { Growth } \\
\left(\mathrm{MgCha}^{-1} \mathrm{yr}^{-1}\right)\end{array}$ & $\begin{array}{c}\text { Coarse } \\
\text { litter } \\
\left(\mathrm{MgCha}^{-1} \mathrm{yr}^{-1}\right)\end{array}$ & $\begin{array}{c}\text { ANPP } \\
\left(\mathrm{MgCha}^{-1} \mathrm{yr}^{-1}\right)\end{array}$ & $\begin{array}{l}\text { Recruitment } \\
\left(\% \mathrm{yr}^{-1}\right)\end{array}$ & $\begin{array}{l}\text { Mean DBH } \\
\quad(\mathrm{cm})\end{array}$ & $\begin{array}{c}\text { AGB } \\
\text { change } \\
\left(\mathrm{MgCha}^{-1} \mathrm{yr}^{-1}\right)\end{array}$ \\
\hline Empirical $^{4}$ & 156 & 1.70 & -2.10 & $6.50^{5}$ & $1.38^{6}$ & 21.1 & NA \\
\hline Stand Model ${ }^{4}$ & 160 & 1.60 & -1.70 & 6.60 & NA & 20.4 & NA \\
\hline ZELIG-TROP $^{1}$ & 178 & 3.09 & -3.03 & 5.39 & 2.33 & 22.3 & 0.02 \\
\hline ZELIG-TROP $^{2}$ & 104 & 2.89 & -2.78 & 5.35 & 3.94 & 18.3 & 0.01 \\
\hline $\mathrm{CLM}^{-\mathrm{CN}^{2}}$ & 135 & 4.91 & -4.93 & 7.83 & NA & NA & 0.00 \\
\hline CLM-CN ${ }^{3}$ & 230 & 4.71 & -4.95 & 7.54 & NA & NA & -0.46 \\
\hline ZELIG Diff. ${ }^{1,2}$ & -74 & -0.20 & 0.25 & -0.04 & 1.61 & -4.0 & 0.01 \\
\hline ZELIG Diff. 1,3 & -40 & 0.20 & -0.46 & -0.33 & 1.08 & 4.6 & -0.17 \\
\hline CLM Diff. 1,2 & -134 & 0.03 & -0.11 & 0.02 & NA & NA & -0.04 \\
\hline CLM Diff. ${ }^{1,3}$ & -39 & -0.17 & -0.15 & -0.27 & NA & NA & -0.50 \\
\hline
\end{tabular}

$1=$ no disturbance, ${ }^{2}=$ high disturbance, ${ }^{3}=$ periodic disturbance, ${ }^{4}$ Chambers et al. (2004), ${ }^{5}$ Chambers et al. (2001), ${ }^{6}$ Phillips et al. (2004).
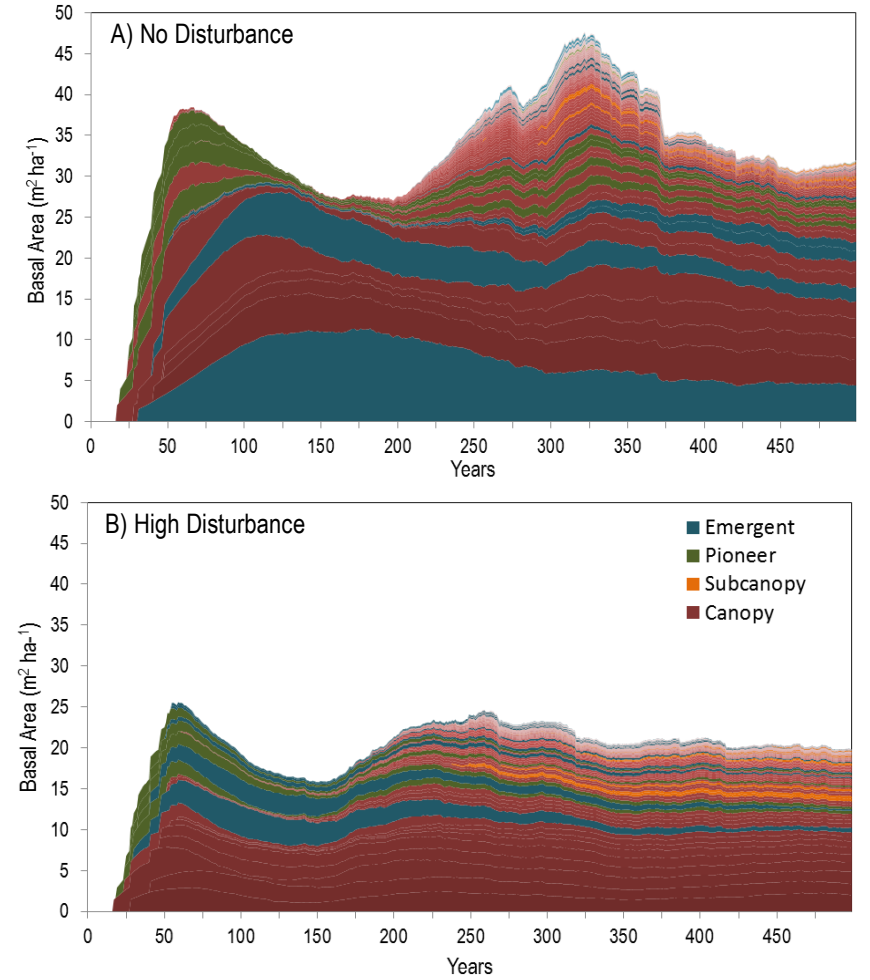

Figure 2. (a) Model simulated successional development for all species modeled in ZELIG-TROP for a central Amazonian forest, separated by canopy growth form (emergent, canopy, sub-canopy, or pioneers). Species composition reported in individual basal area $\left(\mathrm{m}^{2} \mathrm{ha}^{-1}\right)$. (b) Model simulated successional development for all species modeled in ZELIG-TROP after the high-disturbance treatment.

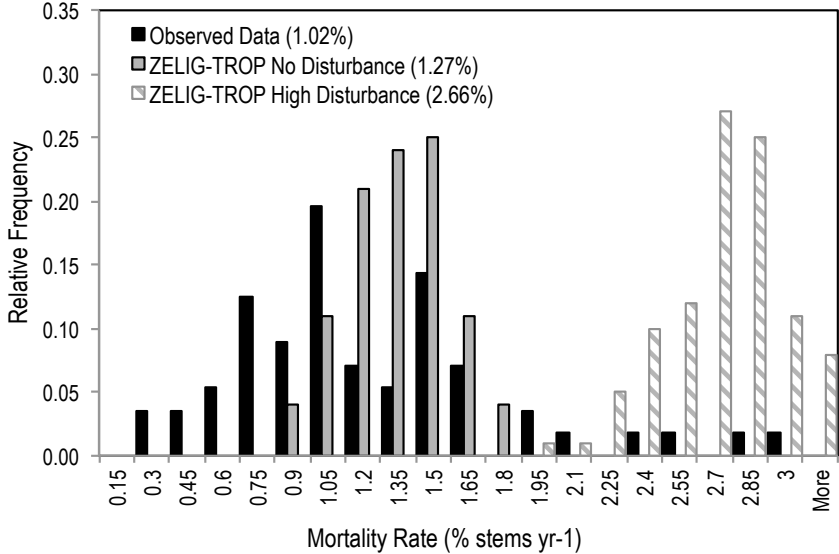

Figure 3. Comparison of relative frequency of annual mortality rates $\left(\%\right.$ stems $\left.\mathrm{yr}^{-1}\right)$ from observed data, ZELIG-TROP nodisturbance, and ZELIG-TROP high-disturbance model data after the disturbance treatment. (Observed data: Chambers et al., 2004).

set, but there was a significant increase in the model results (Fig. 4).

The high-disturbance treatment did significantly reduce AGB in the central Amazon to values similar to the "west and south" counterpart, but wood density was not included in the biomass allometric equation for the central Amazon therefore this reduction in AGB was a "false-positive". Specifically, when the central Amazon was subjected to faster turnover rates there was a significant reduction in AGB (two sample $t$ test, $\left.t_{(99,1.97)}=108.98, p<0.001\right)$ and net carbon loss was $74 \mathrm{Mg} \mathrm{Cha}^{-1}$ (from 178 to $104 \mathrm{Mg} \mathrm{Cha}^{-1}$ ) averaged over the last $100 \mathrm{yr}$ of simulation (Fig. 1d) equivalent to a $41.9 \%$ decrease. AGB in the central Amazon 

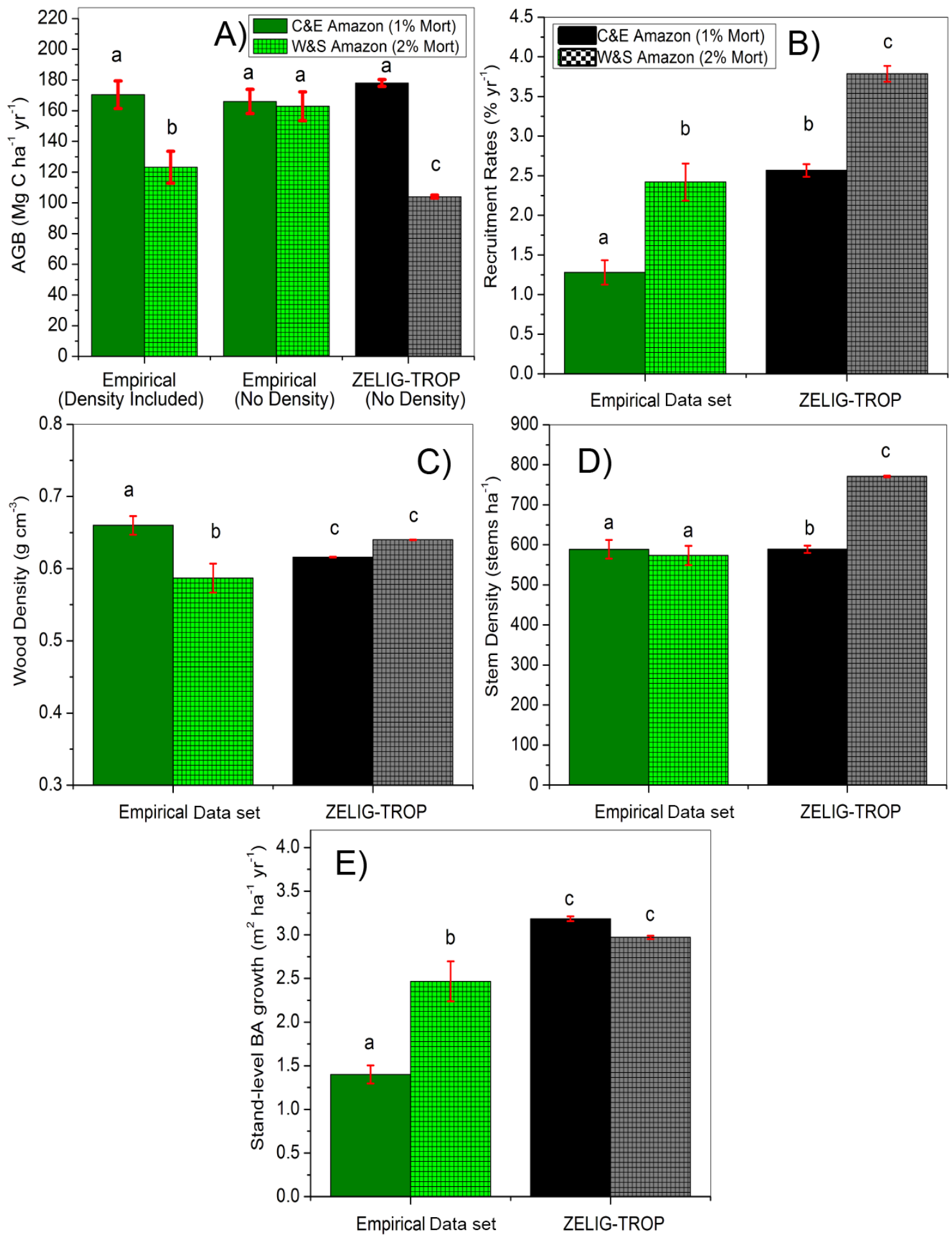

Figure 4. Comparison between "central and eastern" Amazon ("slow dynamics") and "west and south" Amazon ("fast dynamics") between the empirical (RAINFOR data set, green columns) and modeled ZELIG-TROP results for average (a) aboveground biomass (AGB, $\mathrm{MgC} \mathrm{ha}^{-1} \mathrm{yr}^{-1}$ ) with the observed data set either including or not including wood density in the Chambers et al. (2001) allometric equation, (b) recruitment rate $\left(\% \mathrm{yr}^{-1}\right)$, (c) average wood density $\left(\mathrm{g} \mathrm{cm}^{-3}\right)$, (d) stem density (stems ha $\left.{ }^{-1}\right)$, and (e) stand-level basal area (BA) growth rate $\left(\mathrm{m}^{2} \mathrm{ha}^{-1} \mathrm{yr}^{-1}\right)$, with $95 \%$ CIs bars included. Different lowercase letters represent significantly different values using Tukey's multiple comparison, following a one-way ANOVA. 

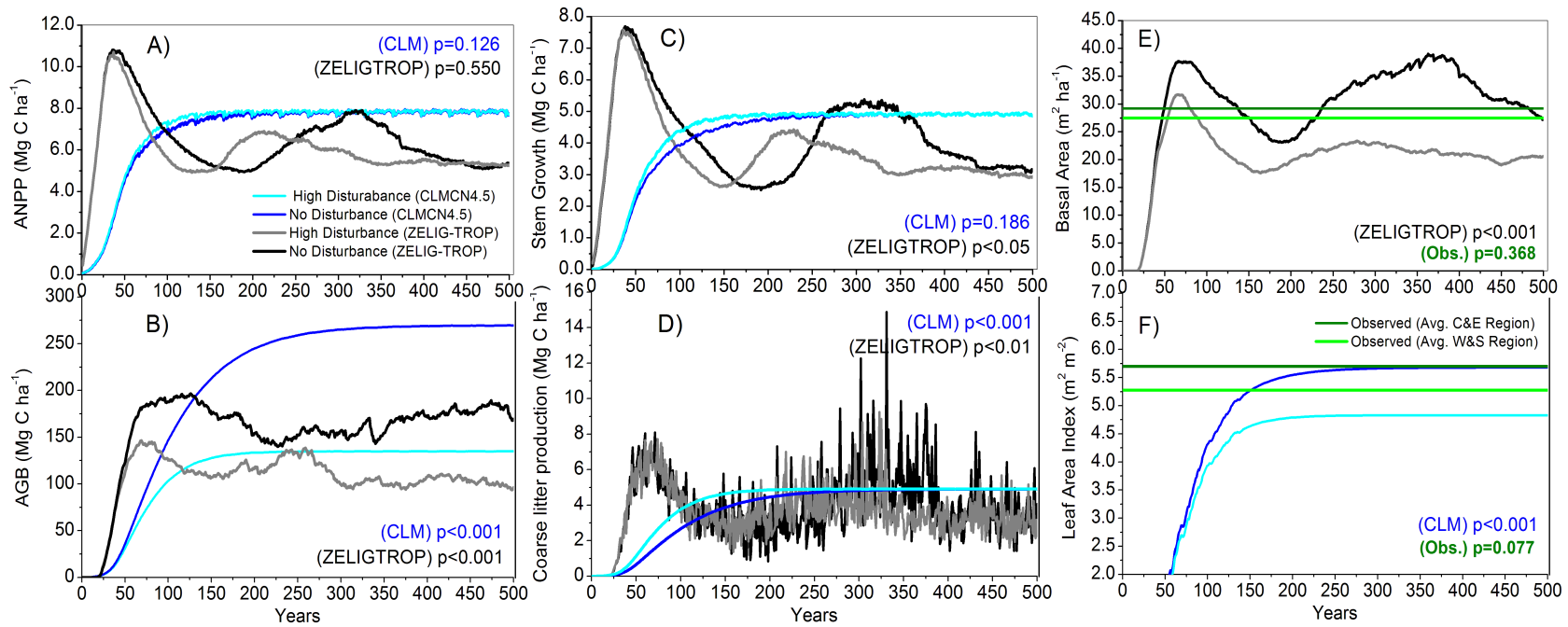

Figure 5. CLM-CN model evaluation and comparisons to ZELIG-TROP for a no-disturbance scenario and a high-disturbance treatment: (a) ANPP, (b) aboveground biomass, (c) stem growth, (d) coarse litter production rates, all measured in $\mathrm{MgCha}^{-1}$, and (e) basal area from ZELIG-TROP and observed data in green as reported by Baker et al. (2004a), and (f) leaf area index (LAI) from CLM-CN4.5 and observed data in green as reported by McWilliams et al. (1993) and Malhi et al. (2013). Statistical significance test in all panels are two-sample Student's $t$ test between the no-disturbance and high-disturbance treatments, separately for each model.

was impacted the most by the high-disturbance treatment. The AGB from the higher disturbed central Amazon was similar (104 Mg Cha $\left.{ }^{-1}\right)$ to AGB values in the "west and south" RAINFOR network plots, but only when comparing to biomass equations that included weighting for wood density (Chave et al., 2001; Chambers et al., 2001). For example, AGB predicted by the Chave et al. (2001) equation $\left(107 \mathrm{MgCha}^{-1}\right)$ had no significant difference between the two disturbed regions (two sample $t$ test, $t_{(38,2.7)}=2.29$, considering alpha $=0.01, p=0.03$ ) (Fig. 4a). The significant reduction in stand basal area, and not variation in wood density, was the main driver of decrease in AGB in ZELIGTROP (Fig. 5e). However, there was no significant difference in stand basal area between the empirical data sets in the central and "west and south" plots $(p=0.368)$, a finding also confirmed by Baker et al. (2004a) and Malhi et al. (2006). While net carbon loss was the expected result, it constitutes a "false positive" resulting from omitting wood density in the model estimate of biomass and from an absence of significant difference in stand basal area across the Amazonia field network.

The high-disturbance treatment in the central Amazon led to a significant increase in stem density by 197 stems from 574 to $771 \mathrm{stems} \mathrm{ha}^{-1}$ (34.3\% increase, Fig. 1b, two sample $t$ test, $\left.t_{(99,1.97)}=28.06, p<0.001\right)$. Compared to the regional gradient in the RAINFOR network there was no significant difference between the higher disturbed and the central Amazon empirical data set $\left(573\right.$ stems ha $^{-1}$ vs. 589 stems ha $^{-1}$ ) (two sample $t$ test, $t_{(46,2.01)}=0.84$, $\mathrm{p}=0.4077$, Fig. $4 \mathrm{~d}$ ). ANPP did not significantly alter in the central Amazonian forest under a high-disturbance treatment (two sample $t$ test, $t_{(99,1.97)}=1.54, \mathrm{p}=0.1260$ ), only decreasing ANPP by 0.04 (from 5.39 to $5.35 \mathrm{Mg} \mathrm{Cha}^{-1} \mathrm{yr}^{-1}$, $1.0 \%$, Fig. 5a). Even with increased disturbance events, ANPP did not decrease in the same manner as biomass due to recovery episodes from more frequent thinning and the increase in smaller stems (i.e., $10 \mathrm{~cm}$ DBH size class) in newly opened gaps. When comparing the stand-level BA growth rates (proxy for productivity) in the RAINFOR network there was a significant increase in growth rates in the "west and south" compared to the central Amazon, but there was no significant difference between the modeled treatments. In fact, an opposite response was seen, and there was a slight decrease as a result of higher disturbance (by $0.21 \mathrm{~m}^{2} \mathrm{ha}^{-1} \mathrm{yr}^{-1}$, Fig. 4e or $0.20 \mathrm{MgCha}^{-1} \mathrm{yr}^{-1}$, Fig. 5c). The model might be inaccurately representing growth rates because prior to applying a higher disturbance regime in the central Amazon, ZELIG-TROP significantly over-estimated the stand-level growth compared to empirical data (3.2 vs. $1.4 \mathrm{~m}^{2} \mathrm{ha}^{-1} \mathrm{yr}^{-1}$ ).

The recruitment rates $\left(\% \mathrm{yr}^{-1}\right)$ from the treatment site constitute the only variable that matched the "west and south" observational data set. Under a high-disturbance treatment in the central Amazon, as expected, there were subsequent increases in recruitment rate, where recruitment significantly increased from 2.3 to $3.9 \% \mathrm{yr}^{-1}$, constituting a $69.1 \%$ increase above no-disturbance recruitment rates (Table 4, Fig. 6a). Pre-treatment, modeled recruitment rates were $0.9 \% \mathrm{yr}^{-1}$ higher compared to empirical values from the central Amazon BDFFP plots (Phillips et al., 2004). Recruitment and mortality rates are tightly linked (Lieberman et al., 1985); therefore, when tree mortality increased, recruitment 

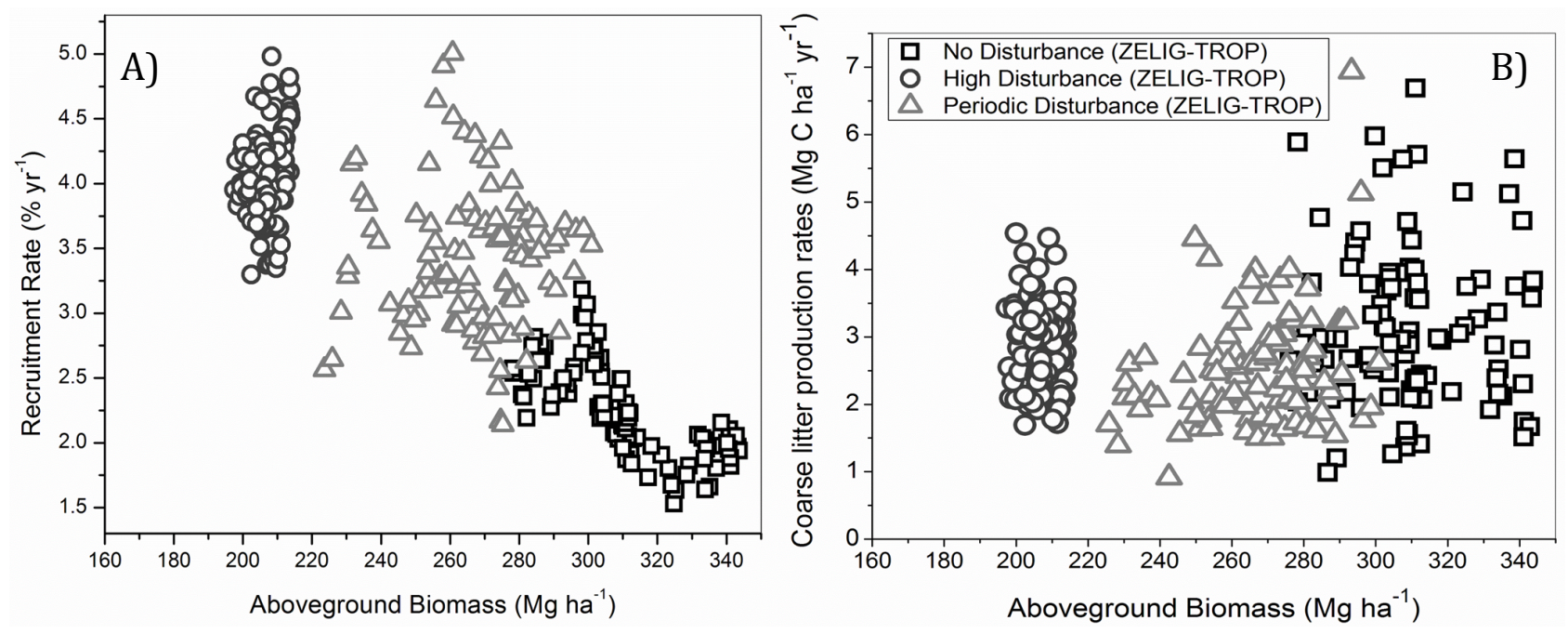

Figure 6. (a) Relationship between aboveground biomass $\left(\mathrm{Mgha}^{-1}\right)$ and recruitment rates $\left(\% \mathrm{yr}^{-1}\right)$. (b) Relationship between aboveground biomass $\left(\mathrm{Mg} \mathrm{ha}^{-1}\right)$ and coarse litter production rates as a result of tree mortality $\left(\mathrm{Mg} \mathrm{Cha}^{-1} \mathrm{yr}^{-1}\right)$, during a no-disturbance, highdisturbance, and periodic disturbance simulation in ZELIG-TROP for the last $100 \mathrm{yr}$ of simulation.

also significantly increased. In the "west and south" empirical data set recruitment rates were $\sim 79 \%$ higher compared to the central region (Fig. 4b). However, while turnover rates increased, there was not an increase in coarse litter production rate (trunks and large stems $>10 \mathrm{~cm}$ diameter, $\mathrm{MgCha}^{-1} \mathrm{yr}^{-1}$, Fig. 6b) compared to the no-disturbance scenario, but rather a significant decrease (two sample $t$ test, $\left.t_{(99,1.97)}=2.70, p<0.01\right)$. Under a high-disturbance treatment, the production of coarse litter decreased by an average of $0.25 \mathrm{MgC} \mathrm{ha}^{-1} \mathrm{yr}^{-1}$ (8.3\%, Table 4). However, it is unclear if this decrease in production of coarse litter is biologically or atmospherically significant.

Once the forest reached a mature stable state (after $500 \mathrm{yr}$ ) the periodic disturbance treatment was applied, removing $20 \%$ of stems in the mature forest every $50 \mathrm{yr}$ (for a duration of $200 \mathrm{yr}$ ). The carbon loss over the $200 \mathrm{yr}$ period, including the four large-scale disturbances, was less severe than the high-disturbance treatment, but was still a significant decrease (two sample $t$ test, $t_{(99,1.97)}=22.73, p<0.001$ ). Compared to the no-disturbance scenario, average AGB net carbon loss was $40 \mathrm{MgCha}^{-1}$ (from 178 to $138 \mathrm{Mg} \mathrm{Cha}^{-1}$, $22.7 \%$, Fig. 7c) and ANPP significantly decreased from an average of 5.39 to $5.06 \mathrm{Mg} \mathrm{Cha}^{-1} \mathrm{yr}^{-1}(6.1 \%$, two sample $t$ test, $\left.t_{(99,1.97)}=7.65, p<0.001\right)$. For the periodic treatment, the decrease in biomass was roughly half the decrease observed in the high-disturbance treatment; however, the decrease in ANPP was more severe.

\subsection{Community composition changes}

The individual-based dynamic vegetation model approach was able to explore the long-term changes to community composition and fate of each species with increased distur- bance. A high-disturbance treatment shifted species composition towards a more even canopy structure, and increased the species evenness and diversity (Fig. 2b). The largest basal area reduction occurred in the most common species; specifically the top two emergent species, followed by the most common canopy species. With an increase in disturbance, the species originally occupying the largest basal area on the plot, Parkia multijuga, decreased by $94.8 \%$ in relative difference in basal area compared to all species averaged over the last $100 \mathrm{yr}$. The next most common emergent species, Cariniana micrantha, decreased by $32.6 \%$ with high disturbance, and canopy species filled in as the dominant growth form (Fig. 2b).

The empirical data set found wood density to be higher in the central region $\left(\sim 0.68 \mathrm{~g} \mathrm{~cm}^{-3}\right)$, and lower in more disturbed "west and south" $\left(\sim 0.57 \mathrm{~g} \mathrm{~cm}^{-3}\right)$ (Baker et al., 2004a). This trend was not seen between the no-disturbance and high-disturbance treatment in the central Amazon, with no significant difference between the treatments (Fig. 4c). Before implementing the high-disturbance treatment average wood density was low for the non-disturbed central forest $\left(0.59 \mathrm{~g} \mathrm{~cm}^{-3}\right.$, similar to values of the "west and south"), and with increased disturbances average wood density increased $\left(0.63 \mathrm{~g} \mathrm{~cm}^{-3}\right)$, an opposite response from empirical trends. Taking a closer look at the community composition and representation of species, the emergent canopy class experienced a decrease in basal area, amounting to $7.8 \%$ of total basal area, compared to $29.6 \%$ prior to high disturbances. The three remaining growth forms all increased in basal area. The emergent species had on average the highest wood density $\left(0.72 \mathrm{~g} \mathrm{~cm}^{-3}\right)$, and the pioneer species had on average the lowest wood density $\left(0.52 \mathrm{~g} \mathrm{~cm}^{-3}\right)$. With a decrease in emergent species, it would seem likely that average 

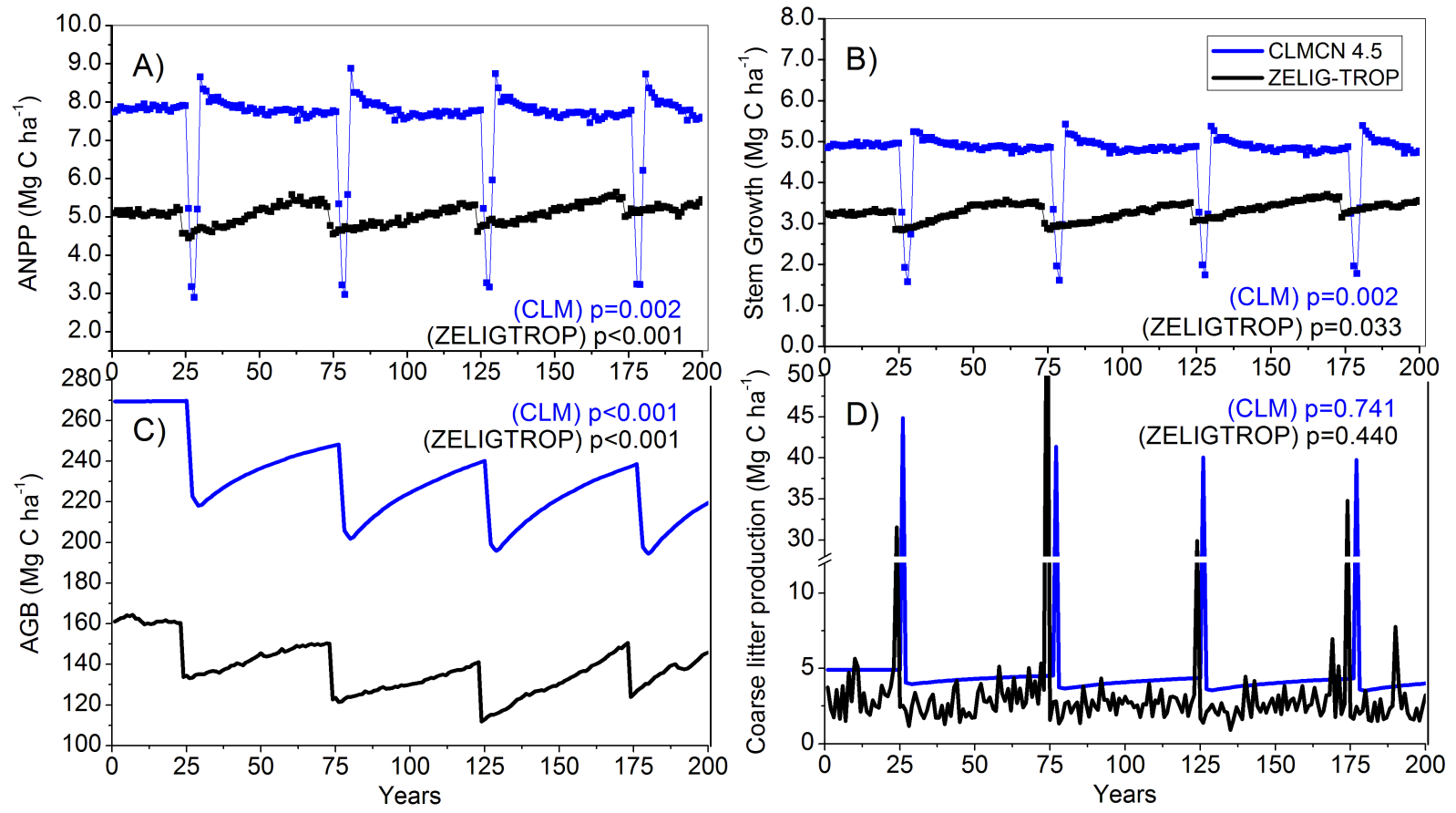

Figure 7. CLM-CN model evaluation and comparisons to ZELIG-TROP for a periodic disturbance treatment: (a) ANPP, (b) stem growth, (c) aboveground biomass (AGB), and (d) coarse litter production rates, all measured in $\mathrm{Mg} \mathrm{Cha}^{-1}$. Statistical significance test in all panels are two-sample Student's $t$ test between the no-disturbance and high-disturbance treatments, separately for each model.

wood density would decrease, as expected in a forest with higher turnover rates. However, the dominant species prior to disturbance (the emergent: Parkia multijuga), which experienced the largest decrease in basal area, had a very low wood density $\left(0.39 \mathrm{~g} \mathrm{~cm}^{-3}\right)$. In addition, even though the emergent size class decreased, the canopy species (which also had high average wood density of $0.71 \mathrm{~g} \mathrm{~cm}^{-3}$ ) basal area increased from $63 \%$ to $79.6 \%$, and the increase in pioneer species from $5.5 \%$ to $5.9 \%$ was not sufficient to lower the total wood density of the forest. With higher disturbance rates subcanopy species represented $6.7 \%$ of the total basal area, compared to $1.7 \%$ prior to high disturbances.

\subsection{Disturbances and carbon change in CLM-CN 4.5 vs. ZELIG-TROP}

After applying a continual disturbance regime within CLM as in ZELIG-TROP, similar patterns in forest biomass in response to disturbance were observed, and both models were in agreement with each other. For example, the relative change in AGB was consistent (41.9\% vs. $49.9 \%$ decrease) for ZELIG-TROP and CLM, respectively (Fig. 5b). In CLM the aboveground carbon storage pools are not determined using allometric equations, but rather through a carbon allocation framework based off of photosynthesis, total GPP, and respiration (Thornton et al., 2002). Including or excluding specific wood density is not considered in CLM. The model outputs from CLM for the disturbed central Amazon also showed a reduction in AGB similar to the "west and south"; which was also a "false-positive" result. The significant loss of LAI with disturbance was the main driver of reduction in AGB (Fig. 5f). There was a weak non-significant difference in LAI between the empirical data sets in the central and "west and south" Amazon regions $(p=0.077)$. Another similarity between the two models was the non-significant change in ANPP; however, ZELIG-TROP predicted a decrease in ANPP while CLM predicted a slight increase in ANPP (Fig. 5a).

With regards to the periodic disturbance treatment of large-scale disturbance events, CLM also replicated analogous patterns in biomass loss and recovery as seen in ZELIGTROP (Fig. 7c). In both models, the sudden decrease in biomass as well as re-equilibration during the recovery phase matched. During each pulse disturbance, the forest lost on average 18.3 and $18.7 \%$ biomass in ZELIG-TROP and CLM, respectively, and gained 16.5 and $15.4 \%$ biomass during the recovery phase. Both CLM and ZELIG-TROP predicted that the recovering forest biomass, on average, was less than the amount lost in each large-scale disturbance event, therefore generating a negative total $\triangle \mathrm{AGB}(-0.15$ and $0.46 \mathrm{Mg} \mathrm{Cha}^{-1} \mathrm{yr}^{-1}$ for ZELIG-TROP and CLM, respectively, Table 4). The negative total $\triangle \mathrm{AGB}$ was less in ZELIGTROP, and was likely attributed to ZELIG-TROP predicting growth rates to significantly increase (by $0.20 \mathrm{Mg} \mathrm{Cha}^{-1}$ $\mathrm{yr}^{-1}$, two sample $t$ test, $\left.t_{(99,1.97)}=2.14, p<0.05\right)$, most likely due to the open gaps from disturbance; therefore, 
losses were damped in ZELIG-TROP. In contrast CLM had growth rates that on average decreased, due to the sharp decrease in growth rates following each large-scale disturbance event (Fig. 7b). Both models also showed that each subsequent recovery period was always greater than the previous period, up to a point where re-growth matched the biomass lost in the disturbance event (Fig. 7c).

There were discrepancies with the response of ANPP to the periodic large-scale forest mortality and recovery events between CLM and ZELIG-TROP. The immediate decrease in ANPP following the large-scale disturbance event was significantly greater in CLM compared to ZELIG-TROP (4.7 vs. $0.6 \mathrm{Mg} \mathrm{Cha}^{-1} \mathrm{yr}^{-1}$, Fig. 7a). The subsequent shape of ANPP during the $50 \mathrm{yr}$ recovery was also different between the two models. CLM predicted that within approximately two years after the disturbance, ANPP returned to pre-disturbance levels and stayed relatively constant until the next disturbance. However, ZELIG-TROP did not display a fast return to pre-disturbance levels, but instead predicted a gradual increase in ANPP after each disturbance. Comparing the no-disturbance scenario and the periodic treatment, both models predicted that overall ANPP significantly decreased with periodic disturbances (two sample $t$ test, $p<0.001$ and $p=0.002$ for ZELIG-TROP and CLM, respectively); however, the gap model predicted a greater percent difference in average ANPP; a $6.1 \%$ decrease vs. $3.5 \%$ decrease in CLM.

To answer our last research question, what are the differences after increasing disturbance rates in ZELIG-TROP vs. CLM for the central Amazon, we did find other discrepancies. While the magnitude of change between AGB was similar between the two models, CLM differs greatly from ZELIG-TROP in that it did not captured the inter-annual variability in carbon stocks, while ZELIG-TROP did (Fig. 5b). Therefore, the demographic forest model captured large fluctuations in annual forest biomass and carbon stocks as a result of either gap dynamics, changes in competition for resources, and/or varying size class and age class structure of the forest. In addition, CLM did not produce pulses of coarse litter in response to tree mortality representative of a heterogeneous landscape (Figs. 5d, 7d). While the relative change in AGB was consistent between the two models, there was a large overestimation in the absolute values. With the inclusion of the high-disturbance treatment CLM predicted that average AGB net carbon loss was $134 \mathrm{Mg} \mathrm{Cha}^{-1}$ (from 269 to $135 \mathrm{MgC} \mathrm{ha}^{-1}$ ) vs. $74 \mathrm{Mg} \mathrm{Cha}^{-1}$ in ZELIG-TROP.

\section{Discussion}

\subsection{Elevated forest disturbance and long-term impacts}

Disturbance is likely to increase in Amazonian forests. Since the mid-1970s observed tree mortality and recruitment rates have been increasing in the Amazon (Phillips et al., 2004), and higher than usual mortality rates have also been associ- ated with droughts and strong windstorm events (Nepstad et al., 2007; Chambers et al., 2009; Phillips et al, 2009; NegrónJuárez et al., 2010; Lewis et al., 2011), each of which could increase with human-induced climate change. In addition, reported mortality rates might be underestimated as $9.1-16.9 \%$ of tree mortality was missing from plot-based estimates in the Amazon (Chambers et al., 2013). We first investigated the impact of continual high disturbance $(100 \mathrm{yr})$ in a central Amazonian forest using a demographic forest model as a benchmark model due to operating at finer scales and having mechanistic mortality algorithms. The elevated disturbance resulted in a decrease in AGB by $41.9 \%$, with essentially no change in ANPP (1.0\% decrease), and an increase in recruitment rates by $69.1 \%$. As a result of higher proportion of smaller stems ( $20.7 \%$ increase in the $10-30 \mathrm{~cm}$ DBH size classes), and decrease in large stems, there was a significant decrease in coarse litter production rate of $8.3 \%$.

We compared empirical data from the higher disturbed "west and south" Amazon plots ("fast dynamics"), to the modeled central Amazonian forest with mirrored tree mortality to evaluate if the models used in this study could predict similar forest dynamics and characteristics. Only one attribute that is tightly linked with disturbances (i.e., increase in recruitment) followed the same pattern when shifting from low disturbance to high disturbance. The models were not successful in predicting the shift in growth rates and specific wood density; forest processes and traits that have been shown to differ with varying turnover rates (Baker et al., 2004a; Lewis et al., 2004; Phillips et al., 2004). Therefore, results showed that the disturbance regime alone might not explain all of the differences in forest dynamics between the two regions, or the models do not accurately capture all disturbance and recovery processes. Furthermore, the net loss in biomass was assumed to be a "false-positive" in the models because in ZELIG-TROP AGB loss was driven by basal area loss, and in CLM AGB loss was driven by LAI loss. Basal area and LAI are not found to be drivers of AGB loss, or patterns of biomass, in empirical data sets (Baker et al., 2004a; Malhi et al., 2006). In contrast basal area varied only slightly across the Amazon plot network (27.5 vs. $29.9 \mathrm{~m}^{2} \mathrm{ha}^{-1}$, Baker et al., 2004a). This indicates that wood density, which is a strong indicator of functional traits (Whitmore, 1998); along with patterns of family composition are strong drivers in steady-state AGB variation.

One study using the RAINFOR network found that variation in wood density drives the pattern in regional-scale AGB (Baker et al., 2004a), a trend that was not captured in ZELIGTROP. While wood density is typically found to be higher in the central Amazon and lower in the "west and south" (Baker et al., 2004a; ter Steege et al., 2006; Saatchi et al., 2009), high wood density is also found in northern Peru (Patiño et al., 2009; Saatchi et al., 2009). Next we compared the same disturbance scenario in CLM-CN 4.5 and found with regards to AGB response to disturbance, CLM performed in a very similar behavior to the gap model. CLM did not reproduce 
the temporal variability in coarse litter inputs, and instead remained constant over time. We also compared the response of large-scale periodic disturbances in the two models, and found that CLM captured similar disturbance and recovery patterns as the gap model.

After applying continual and periodic higher disturbance treatments, we did not observe a continual decrease in forest structure or biomass that lead to a new forest successional trajectory. Instead, we found that the Amazonian forest shifted to a new equilibrium state. The outcome of a continual higher disturbance rate generated a stable forest but with less biomass, faster turnover, higher stem density consisting of smaller stems, as well as less emergent species, less ANPP, and less contribution of coarse litter inputs. Inventory studies have reported that with increased turnover, there is a change in community composition, less wood density, and when these traits are taken into account there is also less AGB (Baker et al., 2004a). We conclude that including wood density in dynamic vegetation models is needed. While we have shown that terrestrial biomass will decrease with increased disturbances, the interacting effects from potential $\mathrm{CO}_{2}$ fertilization should be explored.

\subsection{Disturbance, biomass accumulation, and $\mathrm{CO}_{2}$ fertilization}

Demographic vegetation models are useful tools at predicting long-term temporal trends related to changes in carbon stocks and fluxes. The offsetting interactions between possible $\mathrm{CO}_{2}$ fertilization and disturbances are an important next step to evaluate. Based on observational studies from permanent plots there has been an increase in tree biomass in Amazonian forests by $\sim 0.4-0.5 \mathrm{tC} \mathrm{yr}^{-1}$ over the past three decades (Lewis et al., 2004; Phillips et al., 1998, 2008). $\mathrm{CO}_{2}$ fertilization effects might be an explanation (Fan et al., 1998; Norby et al., 2005), but this is unknown or refuted (Canadell et al., 2007, Norby et al., 2010), and manipulation experiments of enhanced $\mathrm{CO}_{2}$ in the tropics is untested (Zhou et al., 2013). Due to the magnitude of forest growth, $\mathrm{CO}_{2}$ fertilization may not be a causal factor but instead driven by interacting agents such as biogeography and changing environmental site conditions (Lewis et al., 2004; Malhi and Phillips, 2004). The role of widespread recovery from past disturbances still needs to be explored as an explanation for biomass accumulation.

In a study evaluating the risk of Amazonian forest dieback, Rammig et al. (2010) used rainfall projections from 24 GCMs and a dynamic vegetation model (LPJmL) and predicted that Amazonian forest biomass is increasing due to strong $\mathrm{CO}_{2}$ fertilization effects ( 3.9 to $6.2 \mathrm{~kg} \mathrm{C} \mathrm{m}^{-2}$ ), and outweighs the biomass loss due to projected precipitation changes; however, larger uncertainties are associated with the effect of $\mathrm{CO}_{2}$ compared to uncertainties in precipitation. Increasing evidence from an ensemble of updated global climate models are predicting that tropical forests are at a lower risk of forest dieback under climate change, in that they can still retain carbon stocks until 2100 due to fertilization effects of $\mathrm{CO}_{2}$ (Cox et al., 2013; Huntingford et al., 2013); however, there is still large uncertainties between models and how tropical forests will respond to interacting effects of increasing $\mathrm{CO}_{2}$ concentrations, warming temperatures, and changing rainfall patterns (Cox et al., 2013).

In this study over the period of $100 \mathrm{yr}$ there was no significant change in biomass accumulation in both ZELIG-TROP and CLM (Fig. 5b), and the forest did not act as a carbon sink as predicted by empirical studies across a network of Amazon inventory plots (Phillips et al., 1998, 2004). One explanation could be due to atmospheric $\mathrm{CO}_{2}$ being held constant. Upon applying the disturbance treatment, the forest became more stable. With regards to periodic disturbances and sudden tree mortality events, both models predicted a negative $\triangle \mathrm{AGB},-0.15$ and $-0.46 \mathrm{Mg} \mathrm{Cha}^{-1} \mathrm{yr}^{-1}$ for ZELIG-TROP and CLM, respectively; therefore, the forest acted as a carbon source (Table 4). CLM predicted a larger decrease in biomass under periodic disturbances, which offsets the current observed biomass accumulation (lower empirical estimates at 0.20-0.39 $\mathrm{Mg} \mathrm{Cha}^{-1} \mathrm{yr}^{-1}$, Phillips et al., 1998; Chambers and Silver, 2004).

\subsection{Lessons learned from modeling tropical forest disturbance}

\subsubsection{Model comparison to field data and additional sites}

We found that using a dynamic vegetation gap model that operates at the species level was successful at replicating the central Amazonian forest. ZELIG-TROP has also been validated for the subtropical dry forest of Puerto Rico (Holm et al., 2012), but this is the first application of a dynamic vegetation model of this kind (i.e., gap model) for the Amazon Basin. As a result of using species-specific traits, the values reported by ZELIG-TROP for average basal area, AGB, stem density, LAI, and ANPP were all close to observed values (e.g., ranging from 1.7 to $17.1 \%$ difference between ZELIGTROP and observed field results). Field measurements of AGB from the central Amazon transects averaged $( \pm \mathrm{SD})$ : $169 \pm 27.6 \mathrm{MgCha}^{-1}$, and additional field-based measurements from nearby sites in the central Amazon (FLONA Tapajós plots) range from 132 to $197 \mathrm{MgC} \mathrm{ha}^{-1}$ (Miller et al., 2003; Keller et al., 2001). ZELIG-TROP predicted very similar estimates of AGB: $178 \pm 10.5 \mathrm{MgCha}^{-1}$; therefore, model results were within the expected range. From a singlepoint grid cell, located in the same latitude and longitude coordinates as observational plots, CLM predicted higher levels of AGB (269 $\mathrm{Mg} \mathrm{Cha}^{-1}$ ). In a study comparable to ours, Chambers et al. (2004) found that upon doubling turnover rates in an individual-based stand model, forest biomass for a central Amazonian forest decreased by slightly more than $50 \%$. This decrease in forest biomass was similar to the 
response reported in this study (41.9 and $49.9 \%$ ). Unlike the Chambers et al. (2004) study, we did not impose an increase in growth rates in the model parameters in conjunction with elevated turnover rates. Instead, annual growth rates were determined internally within ZELIG-TROP based on speciesspecific parameters and environmental conditions.

\subsubsection{Growth rates and wood density}

Our prediction of average growth rate was higher than field data found in the central Amazon BDFFP inventory plots (3.1 vs. $1.7 \mathrm{MgC} \mathrm{ha}^{-1} \mathrm{yr}^{-1}$, Table 4), but similar to other values found in the central and eastern Amazon. For example, using a process-based model, Hirsch et al. (2004) found aboveground stem growth to be $3.6 \mathrm{MgCha}^{-1} \mathrm{yr}^{-1}$, and field measurements were $2.9 \mathrm{MgC} \mathrm{ha}^{-1} \mathrm{yr}^{-1}$ at the Seca Floresta site in the Tapajós National Forest (Rice et al., 2004). During the high-disturbance treatment, we did not observe an increase in average growth rates compared to the no-disturbance treatment. In fact, there was a slight decrease in annual growth (Table 4, Fig. 4e). This non-significant change in growth rates could have been due to the non-occurrence of large increases in available light and resources after each additional death, a result of a continual disturbance treatment as opposed to a dramatic disturbance event. Alternatively, the western Amazon plots, counterparts to the high-disturbance treatment, did exhibit an increase in growth rates (Fig. 4e). Differences in environmental gradients between regions, such as higher total phosphorous, less weathered, and more fertile soils in the western Amazon (Quesada et al., 2010), could be a stronger controlling factor. In the periodic disturbance treatment, growth and productivity did increase directly following each large-scale disturbance (i.e., removing $20 \%$ of stems). After each pulse disturbance ANPP increased by $14 \%$ over the 50-year recovery phase. The change in community composition under the high-disturbance treatment was also representative of what would be expected (i.e., emergent species decreased by the largest percent in basal area, and canopy and subcanopy species increased); however, by not capturing expected changes in wood density the model might be missing some shifts in species composition in response to disturbance.

Wood density is a robust indicator of life history strategies, growth rates, and/or successional status of a forest (Whitmore, 1998; Suzuki, 1999; Baker et al., 2004a). Upon modeling a central Amazonian forest with disturbance rates similar to the "west and south", the higher disturbance did not create a community composition dominated by pioneer species or lower the average wood density, but instead created a forest of less emergent species, more canopy species, and higher wood density. Our results further confirm that environmental and/or stand factors explain the regional variation of AGB and wood density. Even with elevated disturbance in the central Amazon, the species that persisted and increased in basal area had on average high wood density $\left(0.7 \mathrm{~g} \mathrm{~cm}^{-3}\right)$. The growth-rate scaling coefficients, $G$, used in ZELIG-TROP were inversely correlated with wood density, matching the robust signal observed from inventory data, but was not correlated $\left(r^{2}=0.13\right)$, leading to a possible explanation of the opposite pattern in wood density shifts with increased disturbance. Wood density is not a main parameterization variable in ZELIG-TROP, and other factors in the gap model (e.g., drought or light tolerances, maximum age, availability of light) could be a stronger driver of community composition shifts over wood density.

It should be noted that wood density is difficult to measure accurately in the field, varies between and within species (Chave et al., 2006), varies within a tree across diameter and from the base of the tree to the top (Nogueira et al., 2005), and the Chambers et al. (2001) AGB model without wood density shows that variation of the data explained by the model is strong $\left(r^{2}=0.973\right)$. Including wood density in AGB allometric equations is not required, but it is beneficial for accounting for differences in carbon stocks due to changes in species composition, gradients in soil fertility (Müller-Landau, 2004) as opposed to disturbance regimes, and can be a key variable in greenhouse gas emission mitigation programs.

\subsubsection{CLM 4.5 vs. dynamic vegetation model}

Simulating vegetation demography is beneficial to tracking community shifts, plant competition, and dynamic changes in carbon stocks and fluxes, and should be considered being incorporated into CLM. The version of CLM used here does not take into account differences between plant size, plant age, or all biotic and abiotic stressors. Using demography typical of a gap model will account for these missing factors, will aid in capturing annual carbon variability as a result of heterogeneous mortality across the landscape, and can help improve global land surface models. The exact causes and processes leading to plant mortality are difficult to quantify (Franklin et al., 1987; McDowell et al., 2008, 2011), and additional field research is required in this area, especially in the tropics. However, the gap model approach can quantify the contribution due to natural death, stress related death, or disturbance related death under no-disturbance and highdisturbance scenarios.

The major differences between the gap model ZELIGTROP and CLM in response to higher disturbance rates was as follows: (1) the average AGB net carbon loss was $74 \mathrm{MgCha}^{-1}$ in ZELIG-TROP versus $134 \mathrm{MgCha}^{-1}$ in CLM as a result of doubling background mortality, and (2) the temporal variability in carbon stock and fluxes was not replicated in CLM. While the absolute values in AGB net carbon loss were different between the two models (Fig. 5b), this was due to the fact that ZELIG-TROP was calibrated for a specific location in the central Amazon and CLM using initial conditions representative of the entire Amazon basin. As a result of this distinction, relative differences should be 
used as a comparison tool. The two models were consistent in that they both reached new equilibrium steady states with both continual and periodic disturbances, and therefore the relative change in biomass was analogous between ZELIGTROP and CLM. Temporal variability in carbon stocks and fluxes over time were also absent from the CLM model due to the non-existence of plant demography (i.e., changes in plant size, structure, and age). Regarding the response to periodic disturbances, the major difference between ZELIG-TROP and CLM was the rapid return to pre-disturbance ANPP levels in CLM after each large-scale disturbance event, while in ZELIG-TROP the recovery of ANPP was gradual.

With the inclusion of higher disturbance rates, the two models tested here do predict a $\sim 40-50 \%$ reduction in carbon stocks; however, the drivers that lead to biomass reduction are inconsistent with the empirical driver. Additionally, ZELIG-TROP predicted lower coarse litter production rates, and gains that exceeded losses. CLM predicted higher coarse litter production rates, and losses that exceeded gains (Table 4), but these differences were minimal. However, these differences that we found in gains minus losses between ZELIG-TROP and CLM can lead to inaccurate predictions of carbon response to increasing disturbance rates in integrated assessment models that use CLM. When taking into account the entire Amazon Basin over many years, this discrepancy can significantly affect predictive outcomes when using the global CLM for mitigation strategies.

\subsection{Future directions and summary}

To constrain the future concentration of $\mathrm{CO}_{2}$ into the atmosphere, current mitigation strategies rely heavily on tropical forests to maintain, or increase, as a carbon sink. In order to accurately develop and impose mitigation strategy targets, the land components of earth system models need to more accurately simulate plant mortality, coarse litter inputs, carbon fluxes, and accelerated growth processes associated with disturbance-recovery events. CLM 4.5 has been the model of focus here; however, multiple versions of the Lund-Potsdam-Jena Dynamic Global Vegetation Model (LPJ-DGVM; Sitch et al., 2003), such as LPJ-GUESS (Smith et al., 2001), LPJmL (Bondeau et al., 2007), and LPJSPITFIRE (Thonicke et al., 2010), are notable dynamic vegetation models to evaluate changes to forest biomass in the Amazon (Rammig et al., 2010), and changes to stand structure, plant mortality, and emissions due to fire (Thonicke et al., 2010). Cramer et al. (2001) showed the varying range and uncertainties in ecosystem response and magnitude of the terrestrial carbon sink as a function of rising $\mathrm{CO}_{2}$ and climate change using six DGVMs with varying degrees of functionalities. Including transient changes in vegetation structure while accounting for changes due to elevated disturbance rates requires models to include vegetation dynamics, succession processes, and biogeochemical processes. With the varying degree of capabilities and functionality within vege- tation models this study has benchmarked mortality and disturbance processes in CLM and will benefit the iESM project (Integrated Earth System Model; Jones et al., 2013), which combines CLM with a fully integrated human system component. The capability of tropical forests to act as a carbon sink with and without the inclusion of disturbances needs to be corrected in some models. If not, incorrect predictions of the land uptake could either diminish the effect of mitigation policy, or force more stringent changes in energy infrastructure in order to meet the same climate stabilization targets. Ultimately the contributions to iESM will create the capabilities to test the carbon market and energy market responses to changes in forest mortality and increased disturbances in the Amazon and on a global scale.

It is predicted that disturbances will increase in the future, and this modeling study was unique in that we (1) showed that the drivers that lead to the net loss in carbon stocks in two models are different compared to drivers in empirical data sets, (2) predicted that not all differences in tropical forest attributes (e.g., AGB, basal area growth, stem density, and wood density) can be explained by the disturbance regime alone, and also (3) highlighted some inconsistencies between a detailed gap model and the global community land surface model used in CESM. It was also unique in that we simulated a continual high-disturbance rate, in addition to background mortality during each time step. This set it apart from the majority of disturbance studies that have simulated a onetime total deforestation of the Amazon (Shukla et al., 1990; Henderson-Sellers et al., 1993; Hahmann and Dickinson, 1997; Gedney and Valdes, 2000; Avissar and Werth, 2005). We conclude the following two possibilities in addressing the variations in carbon stocks across the Amazon, but disentangling the contribution of each was beyond the scope of this study. The two models used here incorrectly captured the loss in AGB associated with elevated disturbance, because they attributed the reduced biomass to changes in either basal area or LAI, which is not well supported in the literature. A second possibility is that disturbance is not a strong indicator of regional variation in AGB, but environmental, community composition, and/or stand structure factors are stronger contributors to regional variation in biomass. Our results showed that a simulated central Amazonian forest that mirrored the turnover of the western and southern Amazon continued to differ in multiple forest attributes.

\section{The Supplement related to this article is available online at doi:10.5194/bg-11-5773-2014-supplement.}

Acknowledgements. We would like to thank Edgard Tribuzy for data collection near the ZF2 research station, and support from the Instituto Nacional de Pesquisas da Amazonia, INPA. We would also like to thank the CESM project, sponsored by the 
National Science Foundation (NSF) and the US Department of Energy (DOE), and the administration team that is maintained at the National Center for Atmospheric Research (NCAR). This research was supported by the Director, Office of Science, Office of Biological and Environmental Research of the US Department of Energy under contract no. DE-AC02-05CH11231 as part of the Terrestrial Ecosystem Science (TES) Program, and as part of the Earth System Modeling Program (KP170302). This research used resources of the National Energy Research Scientific Computing Center, which is supported by the Office of Science of the US Department of Energy under contract DE-AC02-05CH11231.

Edited by: K. Thonicke

\section{References}

Anderegg, W. R. L., Kane, J. M., and Anderegg, L. D. L.: Consequences of widespread tree mortality triggered by drought and temperature stress, Nat. Clim. Change, 3, 30-36, 2013.

Avissar, R. and Werth, D.: Global hydroclimatological teleconnections resulting from tropical deforestation, J. of Hydrometer, 6, 134-145, 2005.

Baker, T. R., Phillips, O. L., Malhi, Y., Almeida, S., Arroyo, L., Di Fiore, A., Killeen, T. J., Laurance, S. G., Laurance, W. F., Lewis, S. L., Lloyd, J., Monteagudo, A., Neill, D. A., Patino, S., Pitman, N. C. A., Macedo Silva, J. N., and Vasquez Martinez, R.: Variation in wood density determines spatial patterns in Amazonian forest biomass, Glob. Change Biol., 10, 545-562, 2004a.

Baker, T. R., Phillips, O. L., Malhi, Y., Almeida, S., Arroyo, L., Di Fiore, A., Erwin, T., Higuchi, N., Killeen, T. J., Laurance, S. G., Laurance, W. F., Lewis, S. L., Monteagudo, A., Neill, D. A., Nunez Vargas, P., Pitman, N. C. A., Silva, J. N. M., and Vasquez Martinez, R.: Increasing biomass in Amazonian forest plots, Philosoph. Trans. Roy. Soc. Lond. B, 359, 353-365, 2004 b.

Baraloto, C., Rabaud, S., Molto, Q., Blanc, L., Fortunel, C., Herault, B., Davila, N., Mesones, I., Rios, M., Valderrama, E., and Fine, P. V. A.: Disentangling stand and environmental correlates of aboveground biomass in Amazonian forests, Glob. Change Biol., 17, 2677-2688. 2011.

Bonan, G. B.: Forests and climate change: forcings, feedbacks, and the climate benefits of forests, Science, 320, 1444-1449, 2008.

Bondeau, A., Smith, P., Zaehle, S., Schaphoff, S., Lucht, W., Cramer, W., Gerten, D., Lotze-Campen, H., Müller, C., Reichstein, M., and Smith, B.: Modelling the role of agriculture for the $20^{\text {th }}$ century global terrestrial carbon balance, Glob. Change Biol., 13, 679-706, 2007.

Botkin, D. B., Janak, J. F., and Wallis, J. R.: Some Ecological Consequences of a Computer Model of Forest Growth, J. Ecol., 60, 849-872, 1972.

Brokaw, N. V. L.: Gap-Phase Regeneration in a Tropical Forest, Ecology, 66, 682-687, 1985.

Busing, R. T. and Solomon, A. M.: A comparison of forest survey data with forest dynamics simulators FORCLIM and ZELIG along climatic gradients in Pacific Northwest, Scientific Investigation Report 2004-5078, US Geological Survey, Reston Virginia, USA, 2004.

Canadell, J. G., Le Quere, C., Raupach, M. R., Field, C. B., Buitenhuis, E. T., Ciais, P., Conway, T. J., Gillett, N. P., Houghton, R. A., and Marland, G.: Contributions to accelerating atmospheric
$\mathrm{CO}_{2}$ growth from economic activity, carbon intensity, and efficiency of natural sinks, Proc. Natl. Acad. Sci. USA, 104, 1886618870, 2007.

Canham, C. D. and Marks, P. L.: The response of woody plants to disturbance: patterns of establishment and growth. The Ecology of Natural Disturbances and Patch Dynamics, Academic Press, New York, NY, 1985.

Chamber, J. Q. and Silver, W. L.: Some aspects of ecophysiological and biogeochemical responses of tropical forests to atmospheric change, Phil. Trans. R. Soc. Lond. B, 359, 463-476, 2004.

Chambers, J. Q., Higuchi, N., and Schimel, J. P.: Ancient trees in Amazonia, Nature, 391, 135-136, 1998.

Chambers, J. Q., Schimel, J. P., and Nobre, A. D.: Respiration from coarse wood litter in central Amazon forests, Biogeochem., 52, 115-131, 2001.

Chambers, J. Q., Higuchi, N., Teixeira, L. M., dos Santos, J., Laurance, S. G., and Trumbore, S. E.: Response of tree biomass and wood litter to disturbance in a Central Amazon forest, Oecologia, 141, 596-614, 2004.

Chambers, J. Q., Robertson, A., Carneiro, V., Lima, A., Smith, M.L., Plourde, L., and Higuchi, N.: Hyperspectral remote detection of niche partitioning among canopy trees driven by blowdown gap disturbances in the central Amazon, Oecologia, 160, 107117, 2009.

Chambers, J. Q., Negron-Juarez, R. I., Marra, D. M., Di Vittorio, A., Tews, J., Roberts, D., Ribeiro, G. H. P. M., Trumbore, S. E., and Higuchi, N.: The steady-state mosaic of disturbance and succession across an old-growth Central Amazon forest landscape, PNAS, 110, 3949-3954, 2013.

Chao, K. J., Phillips, O. L., Monteagudo, A., Torres-Lezama, A., and Vasquez Martinez, R.: How do trees die?, Mode of death in northern Amazonia, J. Veg. Sci., 20, 260-268, 2009.

Chave, J., Riera, B., and Dubois, M. A.: Estimation of biomass in a neotropical forest of French Guiana: spatial and temporal variability, J. Trop. Ecol., 17, 79-96, 2001.

Chave, J., Muller-Landau, Baker, T. R., Easdale, T. A., ter Steege, H., and Webb, C. O.: Regional and phylogenetic variation of wood density across 2456 neotropical tree species, Ecol. Appl., 16, 2356-2367, 2006.

Clark, D. A.: Detecting tropical forests' responses to global climatic an atmospheric change: current challenges and a way forward, Biotropica, 39, 4-19, 2007.

Cox, P. M., Betts, R. A., Jones, C. D., Spall, S. A., and Totterdell, I. J.: Acceleration of global warming due to carbon-cycle feedbacks in a coupled climate model, Nature, 408, 184-187, 2000.

Cox, P. M., Betts, R. A., Collins, M., Harris, P. P., Huntingford, C., and Jones, C. D.: Amazonian forest dieback under climatecarbon cycle projections for the 21st century, Theor. Appl. Climatol., 78, 137-156, 2004.

Cox, P. M., Pearson, D., Booth, B. B., Friedlingstein, P., Huntingford, C., Jones, C. D., and Luke, C. M.: Sensitivity of tropical carbon to climate change constrained by carbon dioxide variability, Nature, 494, 341-344, 2013.

Cramer, W., Bondeau, A., Woodward, F. I., Prentice, I. C., Betts, R. A., Brovkin, V., Cox, P. M., Fisher, V., Foley, J. A., Friend, A. D., Kucharik, C., Lomas, M. R., Ramankutty, N., Sitch, S., Smith, B., White, A., and Young-Molling, C.: Global response of terrestrial ecosystem structure and function to $\mathrm{CO}_{2}$ and cli- 
mate change: results from six dynamic global vegetation models, Glob. Change Biol., 7, 357-373, 2001.

Cumming, S. G. and Burton, P. J.: A Programmable Shell and Graphics System for Forest Stand Simulation, Environ. Software, 8, 219-230, 1993.

Dale, V.H., Joyce, L. A., McNulty, S., Neilson, R. P., Ayers, M. P., Flannigan, M. D., Hanson, P. J., Irland, L. C., Lugo, A. E., Peterson, C. J., Simberloff, D., Swanson, F. J., Stocks, B. J., and Wotton, B. M.: Climate change and forest disturbances, Bioscience, 51, 723-734, 2001

DeFries, R. S., Houghton, R. A., Hansen, M. C., Field, C. B., Skole, D., and Townshend, J.: Carbon emissions from tropical deforestation and regrowth based on satellite observations for the 1980s and 1990s, PNAS, 99, 14256-14261, 2002.

Denslow J. S.: Tropical rainforest gaps and tree species diversity, Annu. Rev. Ecol. Syst, 18, 431-451, 1987.

Fan, S., Gloor, M., Mahlman, J., Pacala, S., Sarmiento, J., Takahashi, T., Tans, P.: A Large Terrestrial Carbon Sink in North America Implied by Atmospheric and Oceanic Carbon Dioxide Data and Models, Science, 282, 442-446, 1998.

Fearnside, P. M.: Deforestation in Brazilian Amazonia: History, rates, and consequences, Con- serv. Biol., 19, 680-688, 2005.

Franklin, J.F., Shugart, H. H., and Harmon, M. E.: Tree Death as an Ecological Process, BioScience, Vol. 37, No. 8, Tree Death: Cause and Consequence (September 1987), 550-556, 1987.

Gedney, N. and Valdes, P. J.: The effect of Amazonian deforestation on the northern hemisphere circulation and climate, Geo. Resear. Lett, 27, 3053-3056, 2000.

Hahmann, A. N. and Dickinson, R. E.: RCCM2-BATS model over tropical South America: Applications to tropical deforestation, J. Climate, 10, 1944-1963, 1997.

Henderson-Sellers, A., Dickinson, R. E., Durbidge, T. B., Kennedy, P. J., McGuffe, K., and Pitman, A. J.: Tropical deforestation: modelling local to regional-scale climatic change, J. Geophys. Res., 98, 7289-7315, 1993.

Hirsch, A. I., Little, W. S., Houghton, R. A., Scott, N. A., and White, J. D.: The net carbon flux due to deforestation and forest regrowth in the Brazilian Amazon: analysis using a process-based model, Glob. Change Biol., 10, 908-924, 2004.

Holm, J. A., Shugart, H. H., Van Bloem, S. J., and Larocque, G. R.: Gap model development, validation, and application to succession of secondary subtropical dry forests of Puerto Rico, Ecol. Model., 233, 70-82, 2012.

Huntingford, C., Zelazowski, P., Galbraith, D., Mercado L. M., Sitch, S., Fisher, R., Lomas, M., Walker, A. P., Jones, C. D., Booth, B. B. B., Malhi, Y., Hemming, D., Kay, G., Good, P., Lewis, S. L., Phillips, O. L., Atkin, O. K., Lloyd, J., Gloor, E., Zaragoza-Castells, J., Meir, P., Betts, R., Harris, P. P., Nobre, C., Marango, J., and Cox. P. M.: Simulated resilience of tropical rainforests to $\mathrm{CO}_{2}$-induced climate change, Nature Geosci., 6, 268-273, 2013.

IPCC, Intergovernmental Panel on Climate Change, Climate change 2014: Mitigation of Climate Change, Contribution of working group III to the fifth assessment report of the IPCC, 2014.

Jones, A. D., Collins, W. D., Edmonds, J., Torn, M. S., Janetos, A., Calvin, K. V., Thomson, A., Chini, L. P., Mao, J., Shi, X., Thornton, P., Hurtt, G. C., and Wise, M.: Greenhouse gas policies influence climate via direct effects of land use change, J. Clim., 26, 3657-3670, 2013.
Keller, M., Palace, M., and Hurtt. G.: Biomass estimation in the Tapajos National Forest, Brazil. Examination of sampling and allometric uncertainties, For. Ecol. Manage., 154, 371-382, 2001.

Larocque, G. R., Archambault, L., and Delisle, C.: Modelling forest succession in two southeastern Canadian mixedwood ecosystem types using the ZELIG model, Ecol. Model., 199, 350-362, 2006.

Larocque, G. R., Archambault, L., and Delisle, C.: Development of the gap model ZELIG-CFS to predict the dynamics of North American mixed forest types with complex structures, Ecol. Model, 222, 2570-2583, 2011.

Laurance, W. F., Fearnside, P. M., Laurance, S. G., Delamonica, P., Lovejoy, T. E., Rankin-de Merona, J. M., Chambers, J. Q., and Gascon, C.: Relationship between soils and Amazon forest biomass: a landscape-scale study, For. Ecol. and Manage., 118 , 127-138, 1999.

Laurance, W. F. and Williamson, G. B.: Positive feedbacks among forest fragmentation, drought, and climate change in the Amazon, Conser. Bio., 15, 1529-1535, 2001.

Laurance, W. F., Nascimento, H. E. M., Laurance, S. G., Condit, R., D'Angelo, S., and Andrade, A.: Inferred longevity of Amazonian rainforest trees based on a long-term demographic study, For. Ecol. and Manage., 190, 131-143, 2004.

Le Page, Y., Hurtt G., Thomson A.M., Bond-Lamberty B., Patel P., Wise M., Calvin K., Kyle P., Clarke L., Edmonds J., and Janetos A.: Sensitivity of climate mitigation strategies to natural disturbances, Environ. Res. Lett., 8, 015018, doi:10.1029/2011MS00045, 2013.

Lewis, S. L. Phillips, O. L., Baker, T. R., Lloyd, J., Malhi, Y., Almeida, S., Higuchi, N., Laurance, W. F., Neill, D. A., Silva, J. N. M., Terborgh, J., Torres Lezama, A., Vasquez Martinez, R., Brown, S., Chave, J., Kuebler, C., Nunez Vargas P., and Vinceti, B.: Concerted changes in tropical forest structure and dynamics: evidence from 50 South American long-term plots, Phil. Trans. R. Soc. Lond. B., 359, 421-436, 2004.

Lewis, S. L., Brando, P. M., Phillips, O. L., van der Heijden, G. M. F., and Nepstad, D.: The 2010 Amazon drought, Science, 331, p. 554, 2011.

Lieberman, D., Lieberman, M., Peralta, R., and Hartshorn, G. S.: Mortality Patterns and Stand Turnover Rates in a Wet Tropical Forest in Costa Rica, J. of Ecology, 73, 915-924, 1985.

Lutz, D. A., Shugart, H. H., and White, M. A.: Sensitivity of Russian forest timber harvest and carbon storage to temperature increase, Forestry, 86, 283-293, 2013.

Mailly, D., Kimmins, J. P., and Busing, R. T.: Disturbance and succession in a coniferous forest of northwestern North America: simulation with DRYADES, a spatial gap model, Ecol. Model, 127, 183-205, 2000.

Malhi, Y. and Phillips, O. L.: Tropical forests and global atmospheric change: a synthesis, Philos. Trans. R. Soc. Lond. B. Biol. Sci., 359, 549-555, 2004.

Malhi, Y., Phillips, O. L., Lloyd, J., Baker, T., Wright, J., Almeida, S., Arroyo, L., Frederiksen, T., Grace, J., Higuchi, N., Killeen, T., Laurance, W. F., Leaño, C., Lewis, S., Meir, P., Monteagudo, A., Neill, D., Núñez Vargas, P., Panfil, S. N., Patiño, S., Pitman, N.,Quesada, C. A., Rudas-Ll, A., Salomão, R., Saleska, S., Silva, N., Silveira, M., Sombroek, W. G., Valencia, R., Vásquez Martínez, R., Vieira, I. C. G. and Vinceti, B.: An international network to monitor the structure, composition and dynamics of 
Amazonian forests (RAINFOR), J. of Veg. Sci., 13, 439-450, 2002.

Malhi, Y., Wood, D., Baker, T. R., Wright, J., Phippips, O. L., Cochrane, T., Meir, P., Chave J., Almeida, S., Arroyo, L., Higuchi, N., Killeen, T. J., Laurance, S. G., Laurance, W. F., Lewis, S. L., Monteagudo, A., Neill, D. A., Vargas, P. N., Pitman, N. C. A., Quesada, C. A., Salomao, R., Silva, J. N. M., Lezama, A. T., Terborgh, J., Martinez, R. V., and Vinceti, B.: The regional variation of aboveground live biomass in old-growth Amazonian forests, Glob. Change Biol., 12, 1107-1138, 2006.

Malhi, Y., Timmons Roberts, J., Betts, R. A., Killeen, T. J., Li, W., and Nobre, C. A.: Climate change, deforestation, and the fate of the Amazon, Science, 319, 169-172, 2008.

Malhi, Y., Aragão, L. E. O. C., Galbraith, D., Huntingford, C., Fisher, R., Zelazowski, P., Sitch, S., McSweeney, C., and Meir, P.: Exploring the likelihood and mechanism of a climate-changeinduced dieback of the Amazon rainforest, Proc. Nat. Acad. Sci. USA, 106, 20610-20615, 2009.

McDowell, N. G.: Mechanisms linking drought, hydraulics, metabolism, and vegetation mortality, Plant Phys., 155, 10511059, 2011.

McDowell, N. G., Beerling, D. J., Breshears, D. D., Fisher, R. A., Raffa, K. F., and Stitt, M.: The interdependence of mechanisms underlying climate-driven vegetation mortality, Trends Ecol. Evol., 26, 523-532, 2011.

McWilliam, A. L. C., Roberts, J. M., Cabral, O. M. R., Leitao, M. V. B. R., de Costa, A. C. L., and Zamparoni, C. A. G. P.: Leaf area index and aboveground biomass of terra firme rain forest and adjacent clearings in Amazonia. Funct. Ecol., 7, 310-317, 1993.

McDowell, N., Pockman, W. T., Allen, C. D., Breshears, D. D., Cobb, N., Kolb, T., Plaut, J., Sperry, J., West, A., Williams, D. G., and Yepez, E. A.: Mechanisms of plant survival and mortality during drought: Why do some plants survive while others succumb to drought?, New Phytol., 178, 719-739, 2008.

Miller, S. D., Goulden, M. L., Menton, M. C., Da Rocha, H. R., De Freitas, H. C., Silva Figueira, A. M. E., and Dias de Sousa, C. A.: Biometric and micrometeorological measurements of tropical forest carbon balance, Ecol. App., 14, S114-S126, 2003.

Morton, D. C., DeFries, R. S., Shimabukuro, Y. E., Anderson, L. O., Arai, E., del Bon Espirito-Santo, F., Freitas, R., and Morisette, J.: Cropland expansion changes deforestation dynamics in the southern Brazilian Amazon, Proc. Nat. Acad. Sci. USA, 103, 14637-14641, 2006.

Müller-Landau, H. C.; Interspecific and intersite variation in wood specific gravity of tropical trees, Biotropica, 36, 20-32, 2004.

Nakayama, T.: Shrinkage of shrub forest and recovery of mire ecosystem by river restoration in northern Japan, For. Ecol. and Manage., 256, 1927-1938, 2008.

Negrón-Juárez, R. I., Chambers, J. Q., Guimaraes, G., Zeng, H., Raupp, C. F. M., Marra, D. M., Ribeiro, G. H. P. M., Saatchi, S. S., Nelson, B. W., and Higuchi, N.: Widespread Amazon forest tree mortality from a single cross-basin squall line event, Geo. Res. Lett., 37, L16701, doi:10.1029/2011MS00045, 2010.

Nepstad, D. C., Tohver, I. M., Ray, D., Moutinho, P., and Cardinot, G.: Mortality of large trees and lianas following experimental drought in an Amazon forest, Ecology, 88, 2259-2269, 2007.
Nogueira, E. M., Nelson, B. W., and Fearnside, P. M.: Wood density in dense forest in central Amazonia, Brazil, For. Ecol. Manage., 208, 261-286, 2005.

Norby, R. J., DeLucia, E. H., Gielen, B., Calfapietra, C., Giardina, C. P., King, J. S., Ledford, J., McCarthy, H. R., Moore, D. J. P., Ceulemans, R., De Angelis, P., Finzi, A. C., Karnosky, D. F., Kubiske, M. E., Lukac, M., Pregitzer, K. S., Scarascia-Mugnozza, G. E., Schlesinger, W. H., and Oren, R.: Forest response to elevated $\mathrm{CO}_{2}$ is conserved across a broad range of productivity, Proc. Natl. Acad. Sci., 102, 18052-18056, 2005.

Norby, R. J., Warren, J. M., Iverson, C. M., Medlyn, B. E., and McMurtrie, R. E.: $\mathrm{CO}_{2}$ enhancement of forest productivity constrained by limited nitrogen availability, Proc. Natl. Acad. Sci., 107, 19368-19373, 2010.

O'Brien, S. T., Hayden, B. P., and Shugart, H. H.: Global change, hurricanes and a tropical Forest, Clim. Change, 22, 175-190, 1992.

Overpeck, J. T., Rind, D., and Goldberg, R.: Climate-induced changes in forest disturbance and vegetation, Nature, 343, 5153, 1990.

Pan, Y., Birdsey, R. A., Fang, J., Houghton, R., Kauppi, P. E., Kurz, W.A., Phillips, O. L., Shvidenko, A., Lewis, S. L., Canadell, J. G., Ciais, P., Jackson, R. B., Pacala, S. W., McGuire, A. D., Piao, S., Rautiainen, A., Sitch, S., and Hayes, D.: A large and persistent carbon sink in the world's forests, Science 333, 988-993, 2011.

Patiño, S., Lloyd, J., Paiva, R., Baker, T. R., Quesada, C. A., Mercado, L. M., Schmerler, J., Schwarz, M., Santos, A. J. B., Aguilar, A., Czimczik, C. I., Gallo, J., Horna, V., Hoyos, E. J., Jimenez, E. M., Palomino, W., Peacock, J., Peña-Cruz, A., Sarmiento, C., Sota, A., Turriago, J. D., Villanueva, B., Vitzthum, P., Alvarez, E., Arroyo, L., Baraloto, C., Bonal, D., Chave, J., Costa, A. C. L., Herrera, R., Higuchi, N., Killeen, T., Leal, E., Luizão, F., Meir, P., Monteagudo, A., Neil, D., NúñezVargas, P., Peñuela, M. C., Pitman, N., Priante Filho, N., Prieto, A., Panfil, S. N., Rudas, A., Salomão, R., Silva, N., Silveira, M., Soares deAlmeida, S., Torres-Lezama, A., VásquezMartínez, R., Vieira, I., Malhi, Y., and Phillips, O. L.: Branch xylem density variations across the Amazon Basin, Biogeosciences, 6, 545-568, doi:10.5194/bg-6-545-2009, 2009.

Phillips, O. L., Malhi, Y., Higuchi, N., Laurance, W. F., Nuñez, P. V., Vásquez, R. M., Laurance, S. G., Ferreira, L. V., Stern, M., Brown, S., and Grace, J.: Changes in the carbon balance of tropical forests: evidence from long-term plots, Science, 282, 439442, 1998.

Phillips, O. L., Baker, T. R., Arroyo, L., Higuchi, N., Killeen, T. J., Laurance, W. F., Lewis, S. L., Lloyd, J., Malhi, Y., Monteagudo, A., Neill, D. A., Vargas, P. N., Silva, J. N., Terborgh, J., Martínez, R. V., Alexiades, M., Almeida, S., Brown, S., Chave, J., Comiskey, J. A., Czimczik, C. I., Di Fiore, A., Erwin, T., Kuebler, C., Laurance, S. G., Nascimento, H. E., Olivier, J., Palacios, W., Patiño, S., Pitman, N. C., Quesada, C. A., Saldias, M., Lezama, A. T., and Vinceti, B.: Pattern and process in Amazon tree turnover, 1976-2001, Philos. Trans. R. Soc. Lond. B. Biol. Sci., 359, 381-407, 2004.

Phillips, O. L., Lewis, S. L., Baker, T. R., Chao, K.-J., and Higuchi, N.: The changing Amazon forest, Phil. Trans. R. Soc. B., 363, 1819-1827, 2008.

Phillips, O. L., Aragão, L. E. O. C., Lewis, S. L., Fisher, J. B., Lloyd, J., López-González, G., Malhi, Y., Monteagudo, A., Pea- 
cock, J., Quesada, C. A., van der Heijden, G., Almeida, S., Amaral, I., Arroyo, L., Aymard, G., Baker, T. R., Banki, O., Blanc, L., Bonal, D., Brando, P., Chave, J., Alves de Oliveira, A. C., Dávila Cardozo, N., Czimczik, C. I., Feldpausch, T. R., Freitas, M. A., Gloor, E., Higuchi, N., Jiménez, E., Lloyd, G., Meir, P., Mendoza, C., Morel, A., Neill, D. A., Nepstad, D., Patiño, S., Peñuela, M. C., Prieto, A., Ramrez, F., Schwarz, M., Silva, J., Silveira, M., Sota Thomas, A., ter Steege, H., Stropp, J., Vásquez, R., Zelazowski, P., Alvarez Dávila, E., Andelman, S., Andrade, A., Chao, K., Erwin, T., Di Fiore, A., Honorio, C., Keeling, E., Killeen, H., Laurance, T. J., Peña Cruz, W. F., Pitman, A., Núñez Vargas, N. C. A., Ramrez-Angulo, P., Rudas, H., Salamão, A., Silva, R., Terborgh, N., and Torres-Lezama, J. A.: Drought sensitivity of the Amazon rainforest, Science, 323, 1344-1347, 2009.

Quesada, C. A., Lloyd, J., Schwarz, M., Patiño, S., Baker, T. R., Czimczik, C., Fyllas, N. M., Martinelli, L., Nardoto, G. B., Schmerler, J., Santos, A. J. B., Hodnett, M. G., Herrera, R., Luizão, F. J., Arneth, A., Lloyd, G., Dezzeo, N., Hilke, I., Kuhlmann, I., Raessler, M., Brand, W. A., Geilmann, H., Moraes Filho, J. O., Carvalho, F. P., Araujo Filho, R. N., Chaves, J. E., Cruz Junior, O. F., Pimentel, T. P., and Paiva, R.: Variations in chemical and physical properties of Amazon forest soils in relation to their genesis, Biogeosciences, 7, 1515-1541, doi:10.5194/bg-7-15152010, 2010.

Rammig, A., Jupp, T., Thonicke, K., Tietjen, B., Heinke, J., Ostberg, S., Lucht, W., Cramer, W., and Cox, P.: Estimating the risk of Amazonian forest dieback, New Phytologist, 187, 694-706, 2010.

Rice, A. H., Pyle, E. H., Saleska, S. R., Hutyra, L. R., Palace, M., Keller, M., De Camargo, P. B., Portilho, K., Marques, D. F., and Wofsy, S. C.: Carbon balance and vegetation dynamics in an oldgrowth Amazonian forest, Ecol. Appl., 14, S55-S71, 2004.

Saatchi, S., Malhi, Y., Zutta, B., Buermann, W., Anderson, L. O., Araujo, A. M., Phillips, O. L., Peacock, J., ter Steege, H., Lopez Gonzalez, G., Baker, T., Arroyo, L., Almeida, S., Higuchi, N., Killeen, T., Monteagudo, A., Neill, D., Pitman, N., Prieto, A., Salomão, R., Silva, N., Vásquez Martínez, R., Laurance, W., and Ramírez, H. A.: Mapping landscape scale variations of forest structure, biomass, and productivity in Amazonia, Biogeosciences Discuss., 6, 5461-5505, doi:10.5194/bgd-6-5461-2009, 2009.

Stanford, R. L. Jr.: Fine root biomass under light gap openings in an amazon rain forest, Oecologia, 83, 541-545, 1990.

Seagle, S. W., and Liang, S.: Application of a forest gap model for prediction of browsing effects on riparian forest succession, Ecol. Model., 144, 213-229, 2001.

Shugart, H. H.: Forest Gap Models. Vol. 2, The Earth system: biological and ecological dimensions of global environmental change, Eds. H. A. Mooney and J. C. Canadell in Encyclopedia of Global Environmental Change, John Wiley \& Sons, 316-323, 2002.

Shugart, H. H. and West, D. C.: Development of an Appalachian Deciduous Forest Succession Model and its Application to Assessment of the Impact of the Chestnut Blight, J. of Environ. Manage., 5, 161-179, 1977.

Shugart, H. H., Smith, T. M. and Post, W. M.: The potential for application of individual-based simulation models for assessing the effects of global change, Ann. Rev. Eco. System., 23, 15-38, 1992.
Shukla, J., Nobre, C., and Sellers, P.: Amazon deforestation and climate change, Science, 247, 1322-1325, 1990.

Shuman, J. K., Shugart, H. H., and O'Halloran, T. L.: Sensitivity of Siberian larch forests to climate change, Glob. Change Biol., 17, 2370-84, 2011.

Sitch, S., Smith, B., Prentice, I. C., Arneth, A., Bondeau, A., Cramer, W., Kaplan, J. O., Levis, S., Lucht, W., Sykes, M. T., Thonicke, K., and Venevsky, S.: Evaluation of ecosystem dynamics, plant geography and terrestrial carbon cycling in the LPJ Dynamic Global Vegetation Model, Global Change Biol., 9, 161-185, 2003.

Smith, J. B. and Tirpak, D. A.: Eds. The potential effects of global climate change on the U.S.: Appendix D - Forest. Off. Policy, Planning Eval. Washington, DC: US Environ. Protection Agency, 1989.

Smith, T. M. and Urban, D. L.: Scale and the resolution of forest structural pattern, Vegetatio, 74, 143-150, 1988.

Smith, J. B., Prentice, C. I., and Sykes, M. T.: Representation of vegetation dynamics in the modelling of terrestrial ecosystems: comparing two contrasting approaches within European climate space, Global Ecol. Biogeo., 10, 621-637, 2001.

Solomon, A. M.: Transient response of forests to $\mathrm{CO}_{2}$-induced climate change: Simulations experiments in eastern North America, Oecologia, 68, 567-579, 1986.

Suzuki, E.: Diversity in specific gravity and water content of wood among Bornean tropical rainforest trees, Ecol. Res., 14, 211-224, 1999.

ter Steege, H., Pitman, N. C. A., Phillips, O. L., Chave, J., Sabatier, D., Duque, A., Molion, J.-F., Prevost, M.-F., Spichiger, R., Castellanos, H., von Hildebrand, P., and Vasquez, R.: Continental-scale patterns of canopy tree composition and function across Amazonia, Nature, 443, 444-447, 2006.

Tribuzy, E. S.: Variacoes da temperature foliar do dossel e o seu efeito na taxa assimilatoria de $\mathrm{CO}_{2}$ na Amazonia Central, Master's Thesis, Escola Superior de Agricultura "Luiz de Queiroz", Universidade de Sao Paulo, 2005.

Thonicke, K., Spessa, A., Prentice, I. C., Harrison, S. P., Dong, L., and Carmona-Moreno, C.: The influence of vegetation, fire spread and fire behaviour on biomass burning and trace gas emissions: results from a process-based model, Biogeosci., 7, 19912011, 2010.

Thornton, P. E., Law, B. E., Gholz, H. L., Clark, K. L., Falge, E., Ellsworth, D. S., Goldstein, A. H., Monson, R. K., Hollinger, D., Falk, M., Chen, J., and Sparks, J. P.: Modeling and measuring the effects of disturbance history and climate on carbon and water budgets in evergreen needleleaf forests, Agric. For. Meteor., 113, 185-222, 2002.

Thornton, P. E., Lamarque, J.-F., Rosenbloom, N. A., and Mahowald, N. M.: Influence of carbon-nitrogen cycle coupling on land model response to $\mathrm{CO} 2$ fertilization and climate variability, Glob. Biogeochem. Cyc., 21, GB4018, doi:10.1029/2006GB002868, 2007.

Uhl, C.: Tree dynamics in a species rich forest tierra firme forest in Amazonia, Venezuela, Acta Cientifica Venezolana, 33, 72-77, 1982.

Urban, D. L.: A Versatile Model to Simulate Forest Pattern: A User's Guide to ZELIG Version 1. 0, University of Virginia, Charlottesville, Virginia, 1990. 
Urban, D. L.: Using model analysis to design monitoring programs for landscape management and impact assessment, Ecol. Appl., 10, 1820-1832, 2000.

Urban, D. L., Bonan, G. B., Smith, T. M., and Shugart, H. H.: Spatial applications of gap models, For. Ecol. Manage., 42, 95-110, 1991.

Urban, D. L., Harmon, M. R., and Halpern, C. B.: Potential Response of Pacific Northwestern Forests to Climatic Change, Effects of Stand Age and Initial Composition, Clim. Change, 23, 247-266, 1993.

US DOE: Research Priorities for Tropical Ecosystems Under Climate Change Workshop Report, DOE/SC-0153, US Department of Energy Office of Science, available at: science.energy.gov/ber/ news-and-resources/, 2012.
Whitmore, T. C.: An introduction to tropical rain forests, Oxford University Press, NewYork, 1989.

Wirth, R., Weber, B., and Ryel, R. J.: Spatial and temporal variability of canopy structure in a tropical moist forest, Acta Oecol., 22, 235-244, 2001.

Yang, X., Thornton, P. E., Ricciuto, D. M., and Post, W. M.: The role of phosphorus dynamics in tropical forests - a modeling study using CLM-CNP, Biogeosciences, 11, 1667-1681, doi:10.5194/bg-11-1667-2014, 2014.

Zhou, X., Fu, Y., Zhou, L., and Luo, Y.: An imperative need for global change research in tropical forests, Tree Physiol., 33, 903912, 2013. 